Article

\title{
Knowledge Map of Spatial Planning and Sustainable Development: A Visual Analysis Using CiteSpace
}

\author{
Jiao Zhang ${ }^{1}$, Qian Wang ${ }^{1}\left[\right.$, Yiping Xia ${ }^{2} \mathbb{C}$ and Katsunori Furuya ${ }^{1, *(\mathbb{C})}$ \\ 1 Graduate School of Horticulture, Chiba University, Chiba 271-8510, Japan; \\ 20hd5401@student.gs.chiba-u.jp (J.Z.); 20hd0402@student.gs.chiba-u.jp (Q.W.) \\ 2 Institute of Landscape Architecture, College of Agriculture and Biotechnology, Zhejiang University, \\ Hangzhou 310058, China; ypxia@zju.edu.cn \\ * Correspondence: k.furuya@faculty.chiba-u.jp
}

check for updates

Citation: Zhang, J.; Wang, Q.; Xia, Y.; Furuya, K. Knowledge Map of Spatial Planning and Sustainable Development: A Visual Analysis Using CiteSpace. Land 2022, 11, 331. https://doi.org/10.3390/ land11030331

Academic Editor: Wenze Yue

Received: 20 December 2021

Accepted: 21 February 2022

Published: 24 February 2022

Publisher's Note: MDPI stays neutral with regard to jurisdictional claims in published maps and institutional affiliations.

Copyright: (C) 2022 by the authors. Licensee MDPI, Basel, Switzerland. This article is an open access article distributed under the terms and conditions of the Creative Commons Attribution (CC BY) license (https:// creativecommons.org/licenses/by/ $4.0 /)$.

\begin{abstract}
Spatial planning has become an important measure for countries and regions to promote sustainable development. However, there remains a lack of systematic and quantitative research on spatial planning worldwide. In this study, CiteSpace was used to perform bibliometric analysis and visualization research on the Web of Science core collection and China National Knowledge Infrastructure database. It was found that: (1) The number of papers published in global spatial planning research shows an increasing trend, especially after 2018, with China showing an obvious increasing trend. (2) Globally, the United States has the largest number of relevant research results, and Italy has the most cooperation with other countries. The highest research output is from developed countries, while that of developing countries is relatively weak. (3) There is some intersection among countries, disciplines, and authors but it is not strong, indicating that cooperation should be strengthened. (4) Through keyword cluster, timeline, and time zone analysis, global development can be roughly divided into three stages: the first stage is characterized by the study of spatial planning system theory, the second stage is characterized by building green infrastructure and providing ecological services, and the third stage is characterized by an emphasis on public participation and the establishment of justice mechanisms. China's development corresponds to three stages: the theory and experience learning stage, the spatial planning system focused on economic development stage, and the integration of multiple plans and the sustainable development exploration stage. (5) There are differences in burst words between the world and China, indicating that there are great differences in research hotspots in different countries' periods and conditions.
\end{abstract}

Keywords: spatial planning; sustainable development; knowledge map; CiteSpace

\section{Introduction \\ 1.1. Sustainable Development}

Due to the influence of human activities, climate change, and other factors, the contradiction between human and spatial environments and the imbalance of regional development has become increasingly prominent [1]. The human economy and society are facing unprecedented challenges, and sustainable development concerns the destiny and wellbeing of mankind [2]. In 1987, the World Commission on Environment and Development published a study entitled "Our Common Future", pointing out that sustainable development is "development that can meet the needs of the present without jeopardizing the ability of future generations to meet their needs". The concept has been widely recognized by the international community since its inception. In 2015, the United Nations Sustainable Development Summit formally adopted 17 Sustainable Development Goals (SDGs), aiming to thoroughly solve the social, economic, and environmental development problems in a comprehensive way from 2015 to 2030 [3]. To achieve overall economic and social development, cope with climate change and energy shortages, and promote citizens' health $[4,5]$, 
countries and regions such as Europe, the United States, and Japan have taken the lead in discussing spatial planning, formulating and implementing plans, and accumulating certain experiences, thus establishing the important role of spatial planning in sustainable development. As a community with a shared future, resources, and environments that are the common wealth and basis for the survival of mankind, countries need to strengthen spatial planning exchange and cooperation.

\subsection{Spatial Planning}

The definition of spatial planning has changed with the development of practice. In 1983, the "European Charter for Regional/Spatial Planning" was promulgated, which defined spatial planning as the expression of economic, social, environmental, cultural, and policy in space, with more emphasis on land utilization and management. After World War II, major developed countries and regions used spatial planning as a management tool to prevent market failure and promote post-disaster reconstruction [6]. In recent years, some scholars have been supplementing and enriching the definition of spatial planning, including multiple elements in the spatial planning system, although there has not been a unified definition [7]. However, most of them have established sustainable development as a goal and a framework for action [8,9].

At present, global research on spatial planning involves many projects, such as population, region, city, land, ocean, food, transportation, disaster prevention, and disaster mitigation [10-14]. Especially in the context of emphasizing smart cities, healthy cities, green justice, urban renewal, and other new issues, spatial planning is no longer a single land use management concern, but the overall planning of multiple spatial elements. Spatial planning has become a key tool for achieving sustainable development and addressing climate change $[15,16]$. In the process of implementation, it will face many challenges, such as technological innovation and change, coordination of multiple interests, consideration of equity, and participant well-being [17]. Therefore, systematic bibliometric research is necessary for researchers and decision-makers to review previous studies and understand research hotspots for future development directions.

\subsection{Knowledge Map}

After years of development, spatial planning has become a comprehensive research subject involving multi-disciplines and multi-fields, with a large amount of relevant literature. The traditional literature metrology method has a large workload, and the statistical results are not intuitive, which cannot well summarize the characteristics of previous research and predict the hotspots and directions of future research [18]. A knowledge map is a kind of metrology analysis method; the visualization technology is used to describe knowledge resources and their carriers, mining, analysis, and building, drawing and displaying their mutual connections, with the related research development processes and structure relationships showing as the intuitive graphics, which can be used to understand and predict academic frontiers and dynamics $[3,19,20]$. Lv et al. used various methods to make knowledge maps for the research on global land use planning based on Web of Science (WOS) and studied its hotspots and changing trends [21]. Although spatial planning as an important means of sustainable development has been widely discussed, especially at some international conferences, there have been few scientific metrics visual analysis of it now.

\subsection{CiteSpace}

In recent years, literature on metrology software such as CiteSpace, VOSviewer, and HistCite has emerged, which can effectively help discover research hotspots and their relationships, and draw intuitive and visual knowledge maps [22]. CiteSpace is a literature metrology visualization method developed by Dr. Chaomei Chen's team from Drexel University based on the Java language application [23]. By setting different index values, 
different types of knowledge maps can be obtained, and each view can be analyzed to summarize the evolution path, research development status, focus, and development frontiers.

Due to its strong practicality, CiteSpace has been widely used by academic scholars in various fields in recent years, such as medicine, economics, ecology, and so on. Azam et al. used CiteSpace to make knowledge maps and bibliometric analysis about enhancing mechanical energy harvesting based on the WOS Core Collection (WOSCC) from 2000 to 2020 [24]. Carve et al. made bibliometric maps for the trends in environmental and toxicity research on organic ultraviolet filters by the literature published from 2000 to 2020 based on WOSCC [25]. Ghisi et al. also obtained data from WOSCC between 1975 and 2019 and with the help of CiteSpace reviewed glyphosate and its toxicology [26]. CiteSpace is used for the knowledge structure and research progress in wind power generation from 2005 to 2020 by Azam et al. [27]. With the help of CiteSpace, Daim et al. made a clusters timeline of patent citations of IoT, cybersecurity, and blockchain to forecast technological positioning [28]. Pestana et al. made network science by CiteSpace in determining the intellectual structure, emerging trends, and future research opportunities about senior tourism research, and the data was from Scopus and WOS [29]. Yilmaz et al. conducted scientometric analysis of the life circle assessments in the construction industry by CiteSpace based on WOS from 1997 to 2021 [30]. Obringer et al. used CiteSpace to synthesize the recent literature on smart cities and climate change and discuss the benefits of smart cities in terms of future climate change mitigation and adaptation [31]. A thorough review of a virtual power plant from the perspective of urban sustainability was conducted based on WOS and Scopus between 2000 and 2020, which helped to understand the progress, development, and hot points in the previous research [32]. Carollo et al. used CiteSpace to make a systematic review of the developmental disabilities across the world from 1936 to 2020 based on the Scopus platform [33]. Both VOSviewer and CiteSpace were used by Picone et al. to explore the development of scientific research on marine protected areas, with both Scopus and WOS as the data sources, and the time covers 1993-2020 [34]. Morar et al. made a knowledge domain visualization by CiteSpace to present the important contributions in the development and improvement of the heat integration techniques [35].

Therefore, after the literature review of CiteSpace, we found it has more comprehensive functions and can provide more technical support. Thus, CiteSpace is selected as the main tool of the knowledge map in this study due to its convenience and comprehensiveness. It provides a variety of methods to help find hotspots and research trends. The basic principles are described in Table 1. Based on these principles, this study uses CiteSpace to obtain countries, disciplines, authors, keywords, and main clusters, with the auxiliary of timeline and time zone, and the results can be more intuitive.

Table 1. A brief description of CiteSpace's several operational principles [36,37].

\begin{tabular}{|c|c|}
\hline Methods & Operational Description \\
\hline Keywords & $\begin{array}{c}\text { Keywords are often highly condensed and summarized in an article, and keywords with high frequency } \\
\text { are usually considered as research hotspots. }\end{array}$ \\
\hline $\begin{array}{l}\text { Co-occurrence } \\
\text { analysis }\end{array}$ & $\begin{array}{l}\text { Extracting nominal terms from paper titles, keywords, and conducting co-occurrence analysis of these } \\
\text { nominal terms to show relevant research hotspots. }\end{array}$ \\
\hline Co-citation & $\begin{array}{l}\text { When two or more articles are cited by one or more articles at the same time, a co-citation relationship is } \\
\text { formed. CiteSpace can establish a co-citation network based on the reference database, and then analyze } \\
\text { its centrality in combination with the unified literature network density. Literature with higher centrality } \\
\text { can reflect the basic knowledge of a research field. Co-cited reference topic clusters can better reflect the } \\
\text { development of basic research. }\end{array}$ \\
\hline Cluster & The nodes with a strong correlation between references will be automatically assigned to a certain cluster. \\
\hline Burst Words & $\begin{array}{l}\text { CiteSpace provides the function of "burst words" to screen out the words with a high-frequency change } \\
\text { rate from the time distribution of keywords and determine the frontier fields and development trend of } \\
\text { the discipline by the changing trend of keyword frequency. Words that are used in a short period of time } \\
\text { with a sudden increase in frequency or an extremely rapid increase in growth rate are generally the } \\
\text { research hotspots of this period. }\end{array}$ \\
\hline
\end{tabular}




\section{Research Methods}

\subsection{Data Sources}

WOS is an authoritative literature database widely used in the global field. The core collection database contains four independent databases including SCIE, SSCI, CPCI, and A\&HCI, involving journals, conferences, patents, and other literary types. They come from many disciplines such as natural science, medicine, social science, humanities, and arts.

The China National Knowledge Infrastructure (CNKI) database, which gathers Chinese journal full-text database resources, covers a wide range, and has great academic influence in China [38]. However, due to language reasons, many valuable studies are published and included in the researchers' own countries. Nor can we ignore individual national databases because they can represent the relatively authoritative and new research progress of a country to some extent [39].

Therefore, this study chooses the WOSCC and CNKI database as the sources of literature data, representing the global and Chinese research situation respectively (Figure 1). First, the WOSCC was selected, and literature covering fifteen years from 2006 to 2021 (data as of October 2021) was retrieved under the title of "spatial planning". Literature types were selected as "article" or "review", and unrelated fields such as "chemistry", "medicine", and "pharmacy" were removed. A total of 1898 retrieval results were obtained. The obtained literature data was exported in ".txt" format.

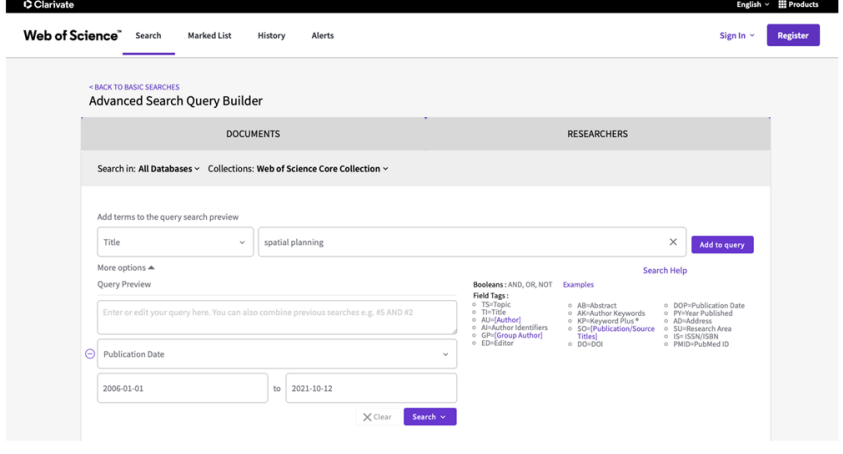

(a)

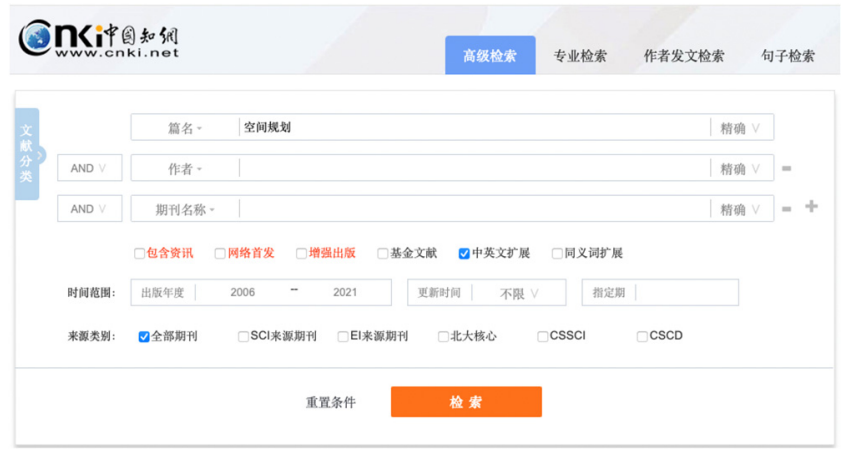

(b)

Figure 1. Advanced search pages for WOSCC (a) and CNKI database (b).

Then CNKI database was selected for Chinese literature retrieval, and literature from 2006 to 2021 (data as of October 2021) was selected with the title of "spatial planning" in Chinese, and 928 valid pieces of literature were extracted. The obtained literature data was exported in "RefWorks" format.

Although CiteSpace has been used for bibliometric analysis of territorial space or land use planning before, they are carried out from the policy perspective of a certain country rather than from the broader perspective of sustainable development, and mainly use separate databases as data sources. At the same time, as introduced in Section 1, the definition of spatial planning has not been unified, but it is widely recognized that it aims at sustainable development and integrates the characteristics of various elements. Thus, spatial planning mentioned in various disciplines such as landscape planning, territorial planning, and rural planning is not distinguished in this study, because it is a multidisciplinary problem to be involved and solved. Taking the upstream term of spatial planning as the research object can facilitate the understanding of the interdisciplinary situation of spatial planning and the development of upstream and downstream disciplines.

To search all references and better understand the intersection of different disciplines, this study adopted the "broad general search strategy" proposed by Dr. Chen, and took "spatial planning" and Chinese "spatial planning" as the search keywords [40,41]. According to Chen's strategy, we confirmed the keywords in literature, books, and authoritative search engines (Wikipedia and Baidu). At the same time, the "advanced search" function 
was enabled for preliminary screening of valid literature, and the literature of medicine, pharmacy, chemistry, and other unrelated fields was removed.

\subsection{Analysis Methods}

CiteSpace constructs the knowledge map mainly through the following steps:

1. CiteSpace needs to configure the Java environment, so the first step is to download and install the latest JRE.

2. Import the data of the database into CiteSpace (Figure 2a). Take the keyword knowledge map as an example and refer to Figure 3 for the specific operation process. The acquisition of each map can be adjusted according to the size of the data volume or other actual conditions.

3. Interpretation (Figure 2b): Each circular node in the knowledge map represents a keyword. The lines between nodes represent the co-occurrence times of keywords; the more lines represent the closer connection between keywords, and the thicker lines represent the greater association strength. Node size indicates the frequency of occurrence of the keyword, and those in the same period are often expressed in the same color [18].

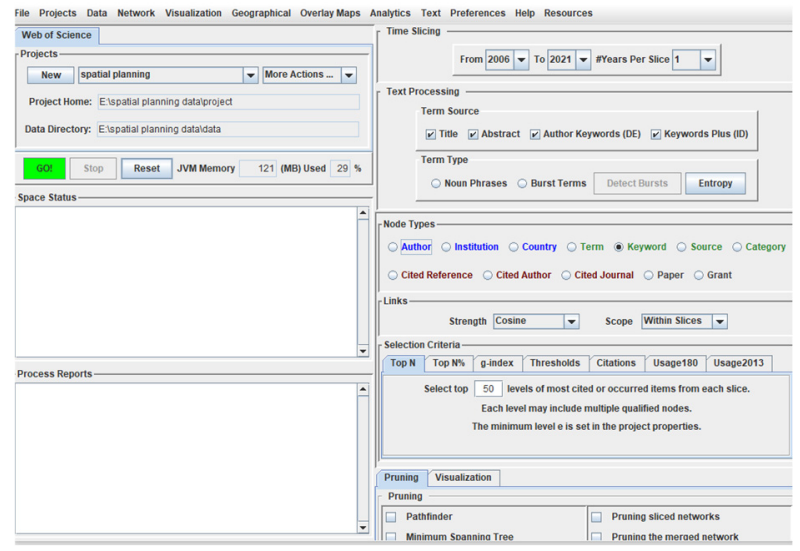

(a)

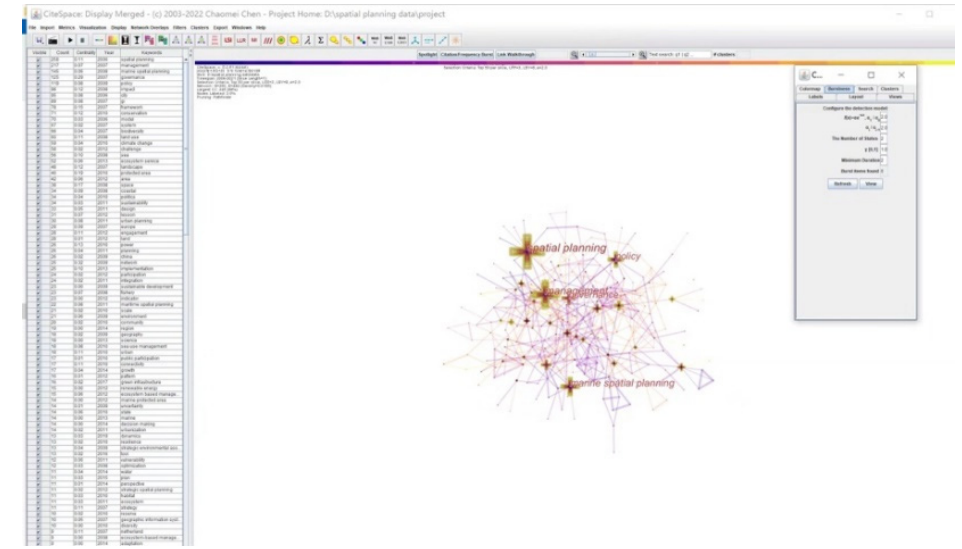

(b)

Figure 2. The original operation interfaces (a) and output interfaces (b).

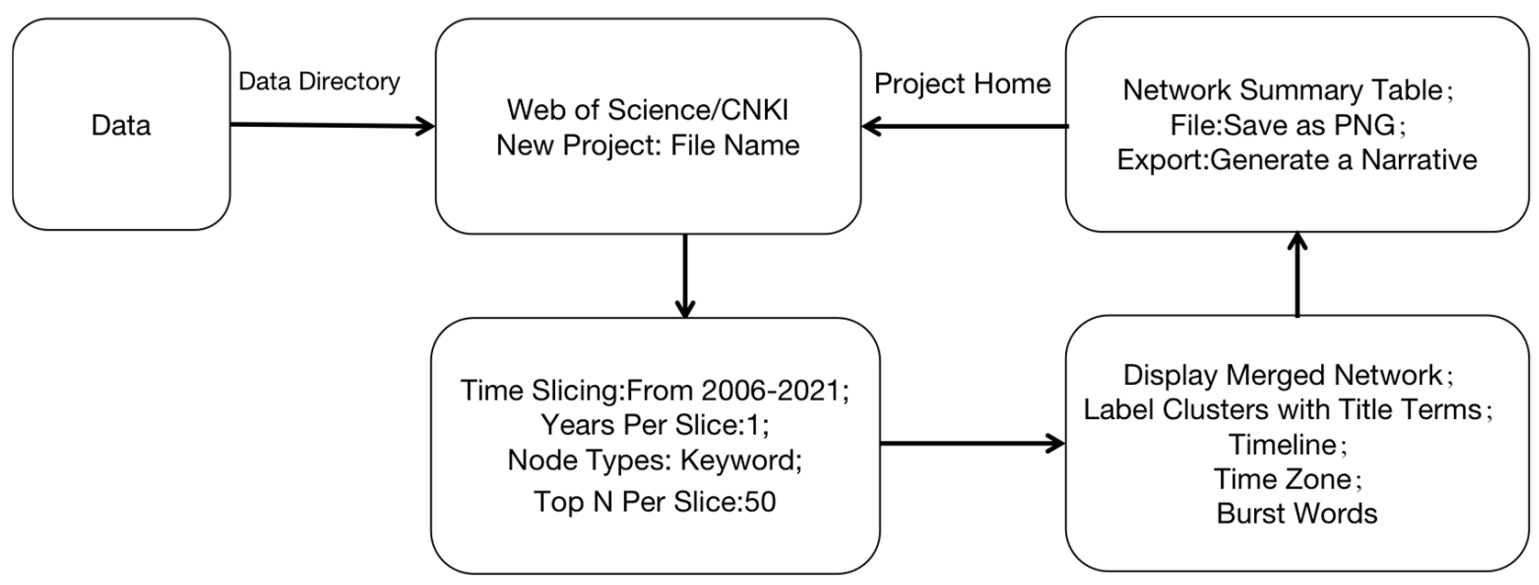

Figure 3. Major visual analytic paths supported by CiteSpace.

After the above steps, knowledge maps of countries, disciplines, authors, keywords, clusters, timeline, time zone, and burst words can be obtained. This study consists of four parts corresponding to the four sections of Section 3. The first part is a preliminary overview of the published literature quantity. The second part is a visual analysis of the 
literature data of the WOSCC using CiteSpace to understand the global research status. The third part uses CiteSpace to analyze the literature of China, the largest developing country with the largest contribution in recent years, in its own authoritative database, which helps to better understand its contribution and research differences. The fourth part compares the burst words in global studies with those in China to analyze the differences in research hotspots.

\section{Results}

3.1. Number of Published Papers on Spatial Planning (2006-2021)

Global spatial planning research has been increasing since 2006 (Figure 4). From the perspective of time, global spatial planning research can be divided into three stages:

1. The 2006-2009 period was a stage of slow development, and there was little research on spatial planning, and it was mainly in the United Kingdom, Europe, and the United States, which was mainly about existing spatial planning theories and exploring new models.

2. The 2010-2015 period was a period of accelerated development, and the number of studies gradually increased.

3. The 2016-2020 period was a more rapid development period, during which spatial planning extended to more disciplines, and the discussions between disciplines were more abundant. The data were collected in October 2021, and so the data for 2021 is incomplete, but even so, the number for 2021 was at least higher than 220.

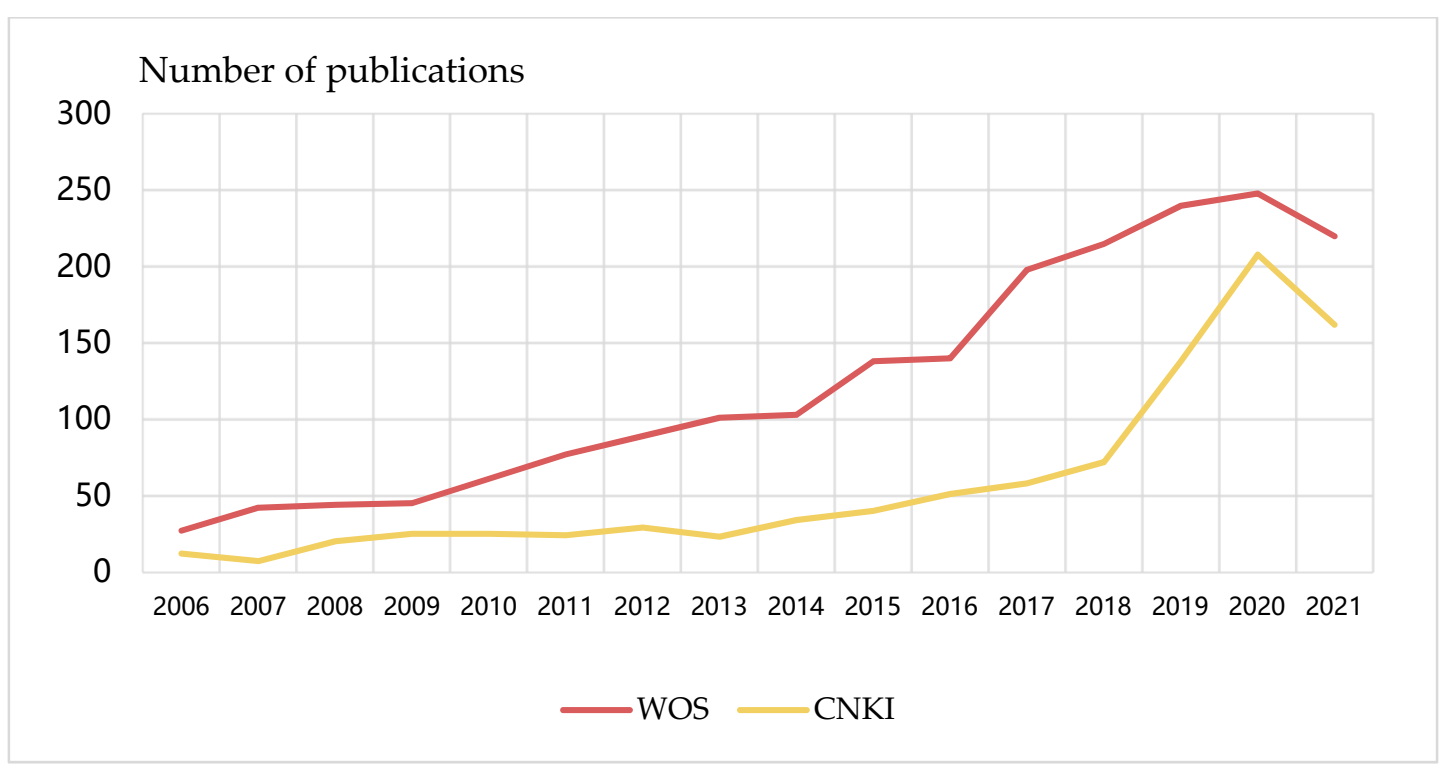

Figure 4. The number of published papers on spatial planning (2006-2021).

China's research on spatial planning started early, but the number of publications has been growing slowly. However, since 2013, spatial planning research has obviously increased, especially after 2018.

China's rapid urbanization focused on the economy and rapid population growth during the specific historical stage, and the government and residents gradually realized that unilateral economic development comes at the expense of the environment and health and is not consistent with a sustainable development strategy. Therefore, the Chinese government issued a series of policies in recent years, and in 2018, established a special department to develop a spatial planning system. In general, research on spatial planning in China started late and has accelerated in recent years. With interdisciplinary discussion, technological innovation, and institutional experience, research heat will continue increasing. 


\subsection{WOSCC}

\subsubsection{Country Collaboration Network}

CiteSpace was used to analyze the countries of publication and a map was generated (Figure 5). The color of the node circle layer represents the change in the author's publication time, the node size represents the number of studies, and the more connected lines the closer cooperation they have. As can be seen from Figure 5, the United States has the largest number of publications in this field, and there are also many published studies in the United Kingdom, Germany, Italy, and China. Italy has conducted the most research in this area in cooperation with other countries.

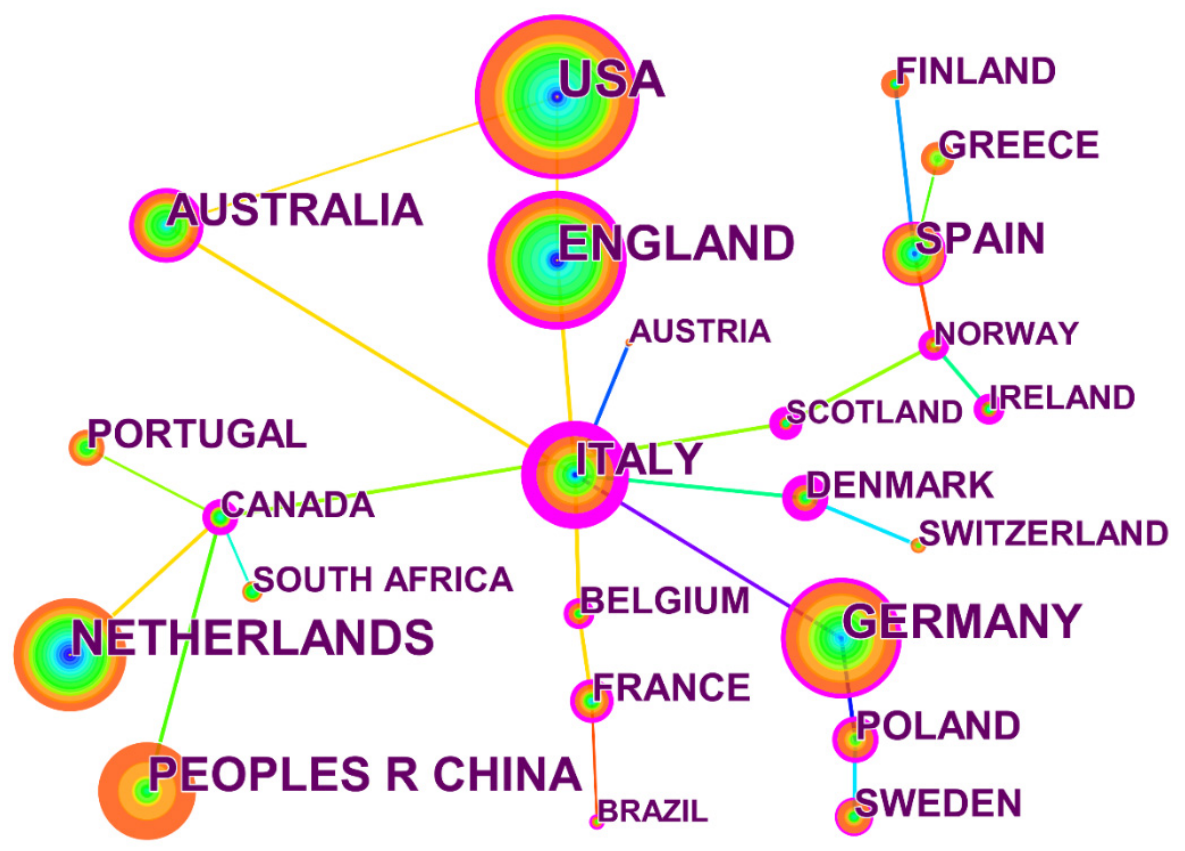

Figure 5. Visualization of the country collaboration network (WOSCC).

However, the outcomes may be influenced by the country's development level, the number of research and publishing institutions, and funding.

Many countries and regions in the world have performed theoretical research and practice on this issue, and because of the actual situation, different methods have been adopted.

In developed countries and regions, after the publication of the "European Spatial Development Outlook 1999" (ESDP) in 1999, Europe, for example, began to try to renew and transform the urban landscape [17]. It cooperated with several countries in trans-regional strategic spatial planning and divided space governance into space policy, financial instruments, and governance frameworks $[40,42,43]$. In the UK, infrastructure planning was improved and developed, land use rights were extended to neighbors, and many social problems, such as spatial inequality, were alleviated to some extent through participatory planning $[44,45]$. The Netherlands established a relatively sound communication, coordination, and public participation mechanism [46]. France integrated the spatial planning system, coordinated stakeholders at different levels, guided and coordinated spatial policies through public services, and has high participation in social organizations [47]. Germany established four different areas of spatial planning: urban design, community development, urban renewal, and regional planning [48,49].

There are other countries that are not shown in Figure 5: after the contradiction and conflict between the centralization of power and the division of the local government, Japan promulgated the "Comprehensive national development plan", which helped to achieve good economic growth results, reduced the income gap, and balanced development [50]. Austria pursued the concept of regional planning to enable mutual recognition and practical transformation of strategies for urban and peripheral areas beyond urban and 
rural categories [51]. Russia faces shrinking cities, while Finland and other countries hold discussions on urban resilience and urban sprawl [52,53]. Thus, we can see that different countries and regions have different discussions and focuses on spatial planning.

The number of studies in developing countries is relatively small, but there remain many issues that need to be addressed, such as green infrastructure (GI) and controlling the size and edge of cities in South Africa [54,55]; Zimbabwe's land, population, economic, and social development inequities [56]; and Indonesian sea level concerns and flood problems [57]. Developing countries are actively involved in discussions and actions: for example, Argentina is exploring the integration of urban native forest land use and urban land use [58]. Turkey is discussing spatial planning in relation to climate and earthquake hazards [59]. Indonesian researchers are integrating participatory geographic information systems into spatial planning regulations [60]. Cambodia and India are trying to assess the current development to provide guidance for the future [61].

Overall, developed countries have higher research levels and closer cooperation (Table 2), while developing countries are relatively weak and vulnerable to natural disasters and climate.

Table 2. Top ten countries with the highest number of papers published on spatial planning (WOSCC).

\begin{tabular}{cccccc}
\hline Country & Frequency & BC $^{\mathbf{a}}$ & Country & Frequency & BC \\
\hline USA & 188 & 0.23 & Italy & 102 & 1.005 \\
England & 156 & 0.48 & Australia & 92 & 0.21 \\
Netherland & 145 & 0.02 & Spain & 79 & 0.19 \\
Germany & 136 & 0.26 & Poland & 54 & 0.2 \\
China & 120 & 0 & Portugal & 52 & 0.07 \\
\hline
\end{tabular}

a Betweenness centrality (BC): A node metric measuring how likely an arbitrary shortest path in a network is to go through the node, which shows the node-to-node connectivity contribution within a network [62].

\subsubsection{Discipline Categories Network}

As can be seen from Figure 6, environmental science and ecology, public administration, regional and urban planning, and other disciplines worldwide pay more attention to spatial planning. Regional and urban planning has a stronger correlation with other disciplines, and there is some crossover between disciplines; however, the overall correlation is not strong.

From an environmental perspective, controlling carbon dioxide emissions, responding to climate change [63-65], and improving energy efficiency have become mainstream public policies [66]. As a coordination framework, spatial planning has become an effective tool for national and local administrations to achieve emission reduction targets $[67,68]$. Therefore, there are many discussions on spatial planning in the field of environment and ecology, such as using spatial planning to provide ecosystem services [69-71], taking ecological value as a resource for the participatory governance planning method for spatial planning and sustainable development [72,73], and carrying out urban development by determining priority protection areas in advance [74].

The urban form and urban planning are also potentially powerful levers for energy transformation, through which deliberate shaping can improve energy efficiency [75]. At the same time, as a policy tool, spatial planning plays an important role in mitigating floods and urban heat island effects, improving residents' access to green space, and protecting natural habitats [12,76].

From an urban perspective, such as accessibility optimization [77], commute time reduction [78,79], land mismatch for building a compact city $[80,81]$, as well as enhancing the quality of urban life, fostering urban growth, facilitating contraction, reducing edge problems [82], establishing ventilated corridors [83], fostering regional resilience and flexibility [84-86], and promoting city resource circulation $[87,88]$, scientific spatial planning is required. In many studies, we can see that various institutions or researchers try to use spatial planning to coordinate urban population [10], land [89,90], and industry to achieve ecological optimization of land use [91,92]. 
To achieve the above goals, the public administration discipline has also fostered the discussion, and tried to integrate sustainable development goals to guide local organizations and planning indices, through a comprehensive administrative system working at all levels to improve citizen or stakeholder participation and autonomy [93-97].

As can be seen from the above, spatial planning has been widely discussed, but the correlation among disciplines is not strong (Table 3). Environmental science and ecology, the subject with the highest frequency, is not strongly correlated with other disciplines because the betweenness centrality (BC) is 0 .

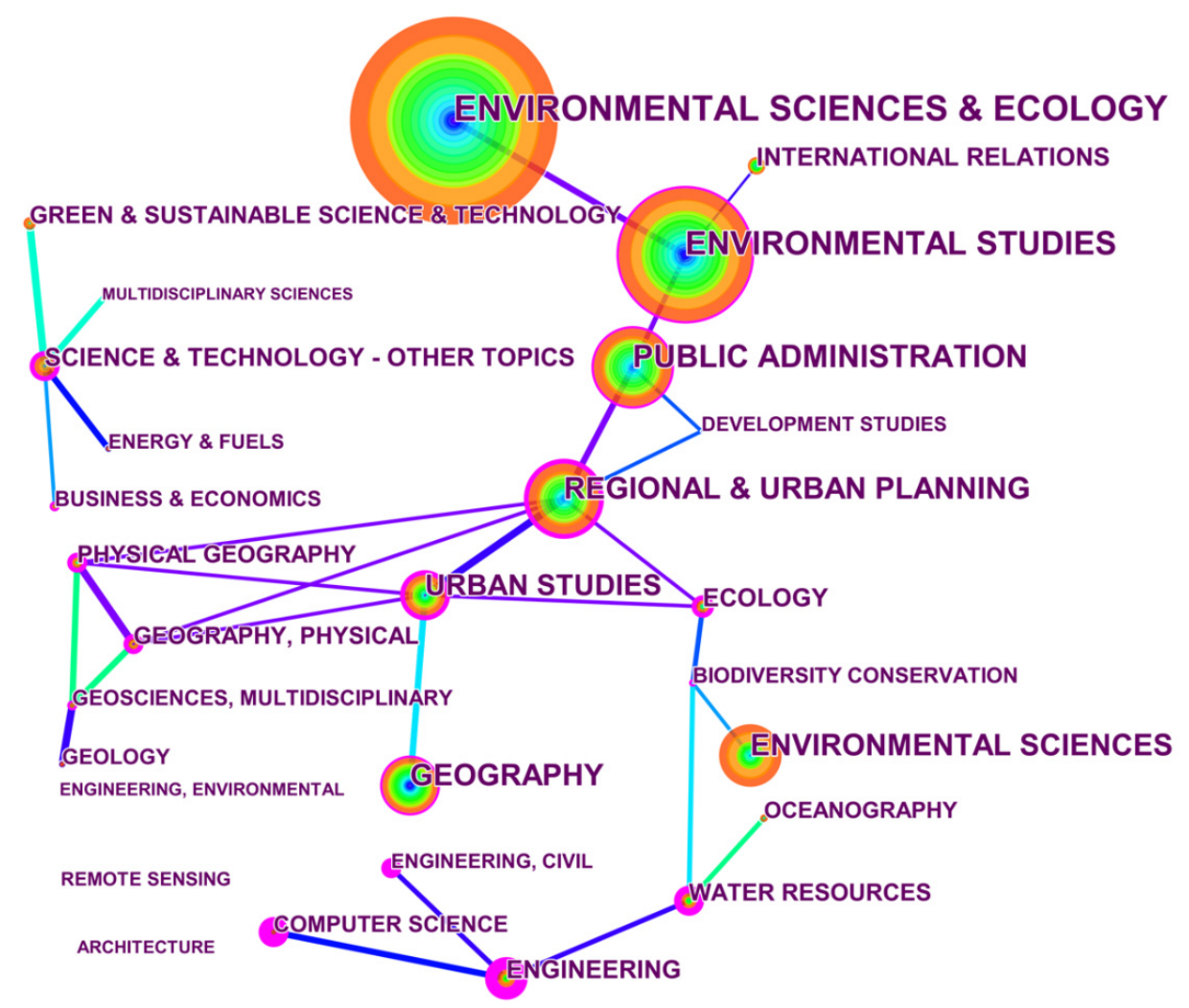

Figure 6. Visualization of the discipline categories (WOSCC).

Table 3. Top ten disciplines in the research field of spatial planning (WOSCC).

\begin{tabular}{|c|c|c|c|c|c|}
\hline Discipline & Frequency & BC & Discipline & Frequency & BC \\
\hline $\begin{array}{l}\text { Environmental } \\
\text { science and } \\
\text { Ecology }\end{array}$ & 742 & 0 & Geography & 245 & 0.2 \\
\hline $\begin{array}{l}\text { Environmental } \\
\text { studies }\end{array}$ & 496 & 0.13 & Urban studies & 193 & 0.28 \\
\hline $\begin{array}{c}\text { Public } \\
\text { administration }\end{array}$ & 319 & 0.2 & Engineering & 112 & 0.29 \\
\hline $\begin{array}{l}\text { Regional and } \\
\text { Urban planning }\end{array}$ & 293 & 0.39 & $\begin{array}{c}\text { Science } \\
\text { Technology- } \\
\text { other } \\
\text { topics }\end{array}$ & 108 & 0.38 \\
\hline $\begin{array}{l}\text { Environmental } \\
\text { science }\end{array}$ & 270 & 0 & Engineering & 106 & 0.89 \\
\hline
\end{tabular}

\subsubsection{Author Analysis (WOSCC)}

The global authors' knowledge map was plotted by CiteSpace, and the following figure (Figure 7) was obtained. Stead D, Calado H, Gee K, and Jay S were key contributors. Stead D reviews the evolution of spatial planning policies based on geopolitical conditions 
in Europe, especially since the 21st century, as well as the research exploring participatory spatial planning [98-101]. The other major authors have studied the sustainable development of marine space and the establishment of a spatial planning system [102-104]. However, at the same time, we can see that, except for the author cluster with Calado $\mathrm{H}$, Gee $\mathrm{K}$, and Jay $\mathrm{S}$ as the main nodes in orange, the cooperation between other authors is not very strong.

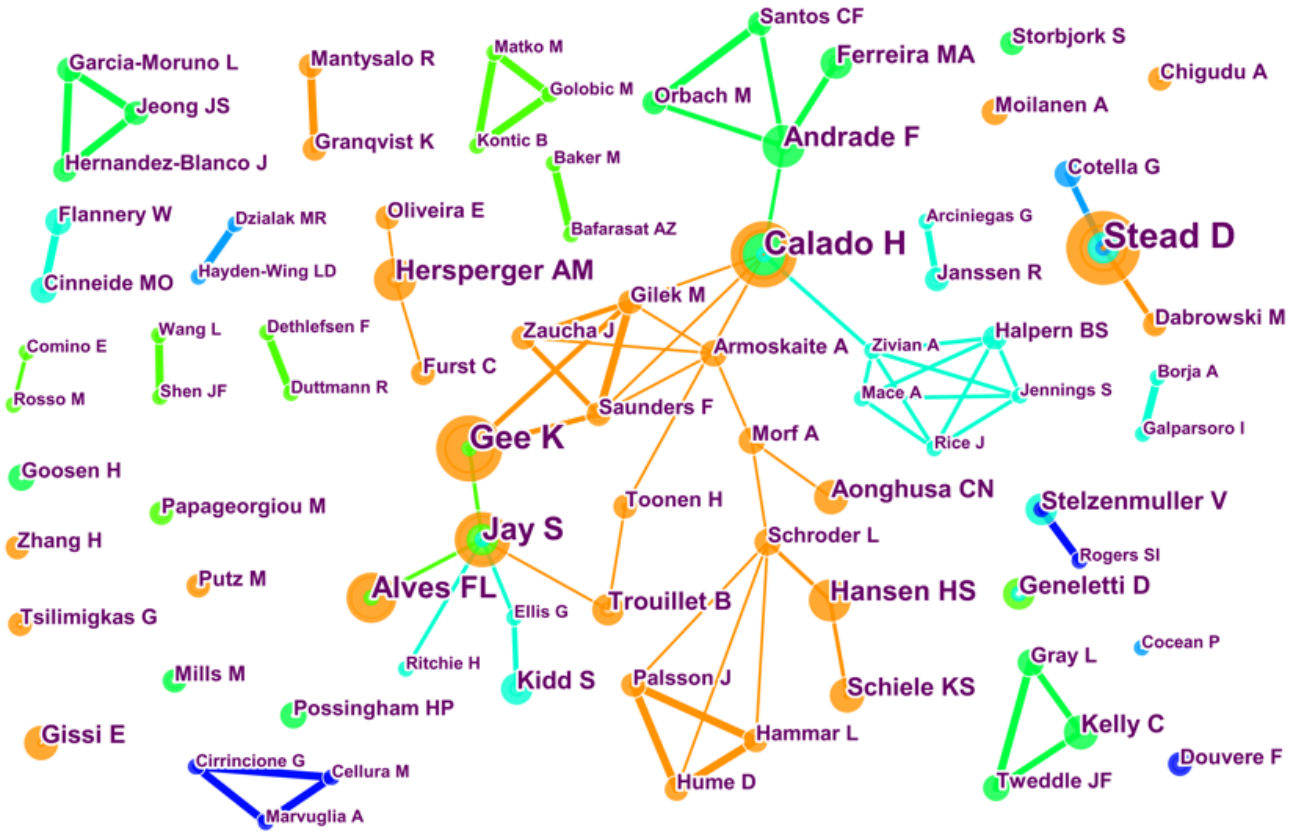

Figure 7. Visualization of the authors' network (WOSCC).

\subsubsection{Time Zone Visualization}

Taking 2006 as the beginning of the timeline, the time zone map of research frontiers was obtained using CiteSpace (Figure 8). The changes in spatial planning research focuses are as follows:

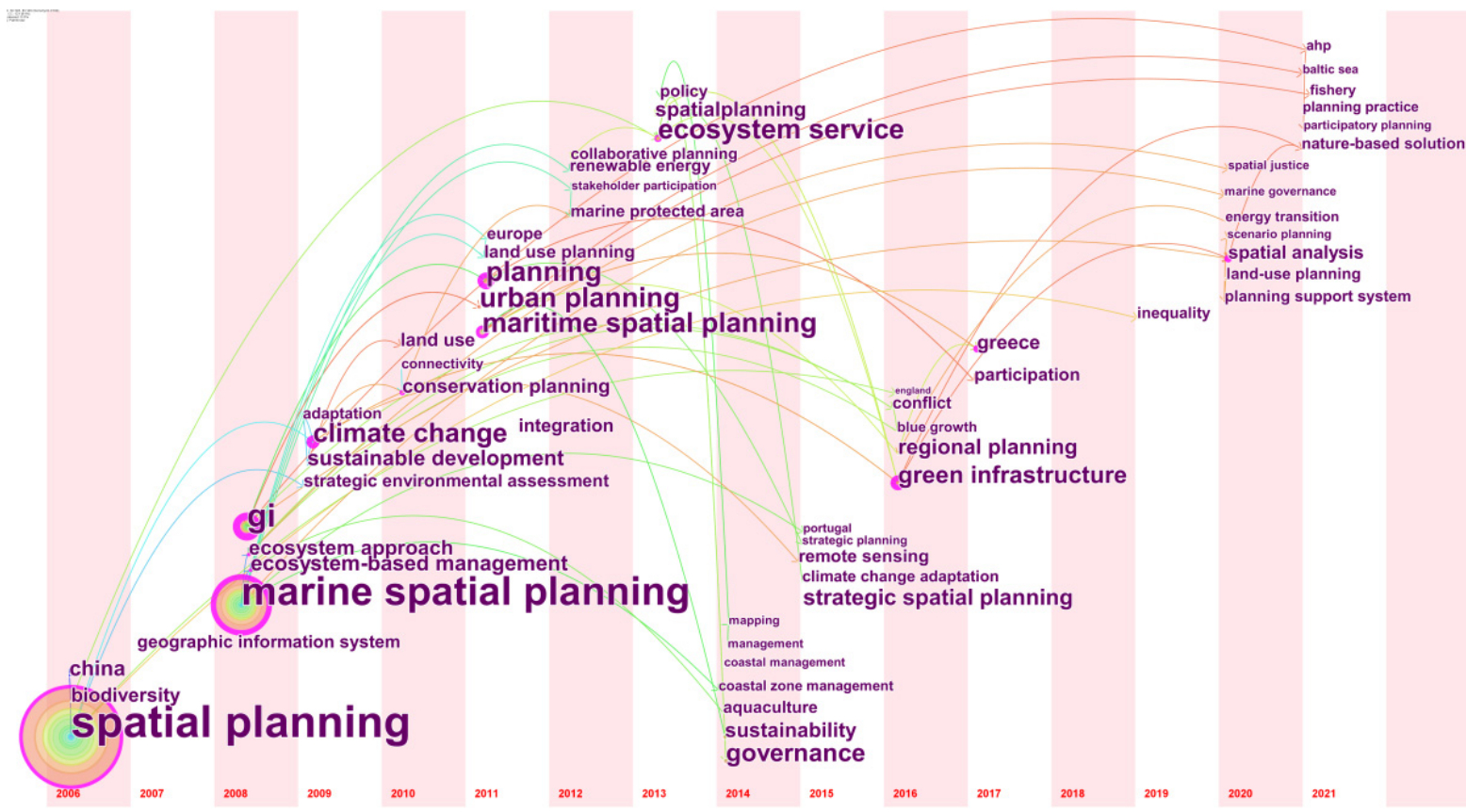

Figure 8. Visualization of time zone (WOSCC). 
Research on "marine space planning" occurred relatively early. Many studies have focused on the discussion of marine spatial planning and ecology $[105,106]$, the interaction between land and sea [107], the determination of marine space utilization for different marine uses, and the promotion of sustainable development of the marine economy [108-110]. China was involved in the spatial planning discussion at a relatively early stage. Since 2009, the problems caused by climate change have become increasingly obvious, and the issue of sustainable development has gradually attracted attention. Researchers have discussed how to solve the problem of sustainable development through spatial planning. Since 2011, the vision of spatial planning has gradually turned to land use and urban planning and has built an ecological service system through spatial planning. In 2013, spatial planning and ecosystem services became increasingly closely linked. In 2014, sustainability became a hot topic in the field of spatial planning. In 2015, more spatial planning strategies were adopted to deal with climate change, and green infrastructure was implemented to address the problem of unbalanced regional development, emphasizing citizen participation, equity, and justice. After 2019, there has not been a significant research hotspot, indicating a continuation of the previous discussion.

Specifically, the discussion on GI has persisted [110]. From 2008 to 2016, countries discussed the importance of integrating GI into spatial planning, providing ecological services [111,112], preventing climate change, and providing habitat protection based on their actual conditions. GI planning is recognized as a new and innovative means of land use planning, which can help mitigate the effects of climate change [113]. Widespread urbanization is a major cause of landscape fragmentation, depleting natural habitats, and affecting climate change. The implementation of GI provides an effective response.

\subsubsection{Co-Citation Analysis (WOSCC)}

In the literature, co-citation cluster and keywords maps were obtained by CiteSpace (Figure 9, Table 4), and there were seven related topic clusters, roughly divided by the time axis slices:

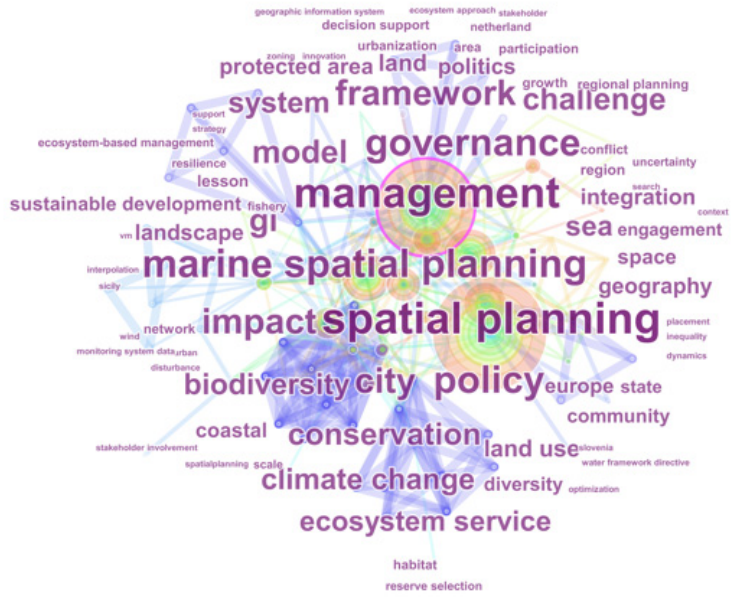

(a)

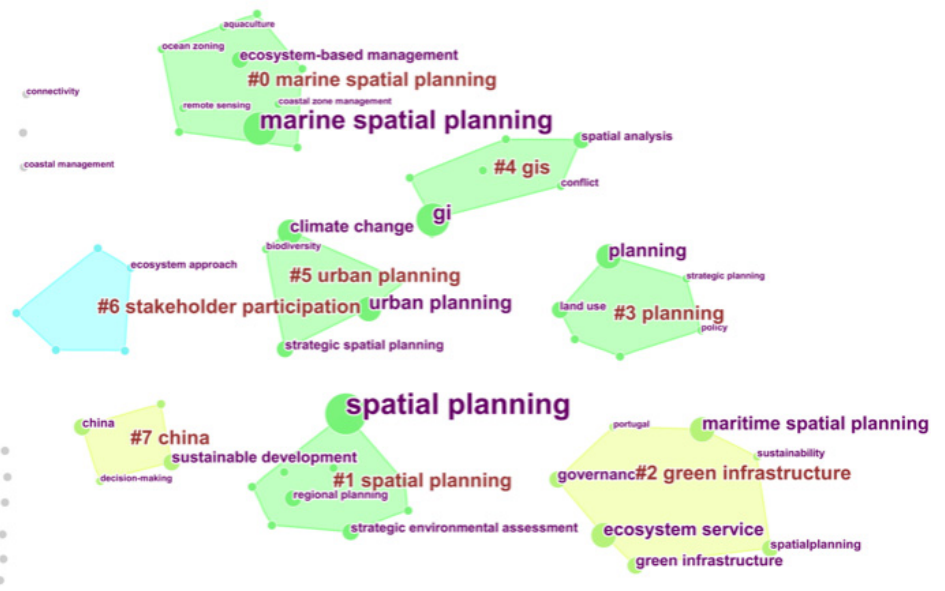

(b)

Figure 9. Visualization of keywords (a) and cluster analysis (b) (WOSCC).

The first stage included four clusters, which formed the exploration stage of spatial planning theory and technology. Based on an analysis of the contained clusters, the evaluation strategies of marine ecological management and urban planning management were explored in this stage, and the land use and GI were preliminarily studied using GIS.

In the second stage, the discussion on the spatial planning and ecosystem service provision of GI continued, and China became a separate cluster topic, indicating that China had started to participate in international spatial planning research and discussion at this stage. 
Table 4. Seven main clusters in the field of spatial planning based on WOSCC.

\begin{tabular}{cccc}
\hline Clustering Number & Keywords Quantity & Mean Contour Value & Average Year \\
\hline 0 & 10 & 0.85 & 2009 \\
1 & 9 & 0.957 & 2010 \\
2 & 7 & 0.96 & 2013 \\
3 & 6 & 0.806 & 2010 \\
4 & 6 & 0.955 & 2012 \\
5 & 5 & 0.879 & 2010 \\
6 & 5 & 0.882 & 2011 \\
7 & 4 & 0.901 & 2013 \\
\hline
\end{tabular}

Overall (Table 5), GI (0.81), marine spatial planning (0.73), urban planning (0.73), and climate change (0.69) were the strongest keywords with centrality. We infer that spatial planning has focused more on the ocean and urban space, and tackling climate change through the construction of GI has been instrumental in spatial planning research.

Table 5. Keyword frequency and betweenness centrality in the field of spatial planning based on WOSCC.

\begin{tabular}{|c|c|c|c|c|c|}
\hline Frequency & BC & Keyword & Frequency & BC & Keyword \\
\hline 145 & 0.73 & marine spatial planning & 32 & 0.2 & planning \\
\hline 14 & 0.16 & $\begin{array}{c}\text { ecosystem-based } \\
\text { management }\end{array}$ & 7 & 0 & land use \\
\hline 5 & 0 & ocean zoning & 4 & 0.05 & policy \\
\hline 4 & 0 & remote sensing & 4 & 0 & strategic planning \\
\hline 4 & 0 & $\begin{array}{l}\text { coastal zone } \\
\text { management }\end{array}$ & 3 & 0.24 & stakeholder \\
\hline 4 & 0 & aquaculture & 3 & 0 & evaluation \\
\hline 2 & 0 & $\begin{array}{l}\text { stakeholder } \\
\text { involvement }\end{array}$ & 54 & 0.81 & GI \\
\hline 2 & 0 & sea use management & 8 & 0 & spatial analysis \\
\hline 2 & 0 & VM & 6 & 0 & conflict \\
\hline 2 & 0.66 & spatial auto correlation & 3 & 0 & integration \\
\hline 258 & 0.8 & spatial planning & 2 & 0 & wind \\
\hline 10 & 0 & $\begin{array}{c}\text { strategic environmental } \\
\text { assessment }\end{array}$ & 2 & 0 & Sicily \\
\hline 7 & 0 & regional planning & 34 & 0.73 & urban planning \\
\hline 3 & 0 & uncertainty & 23 & 0.69 & climate change \\
\hline 3 & 0 & resilience & 10 & 0 & $\begin{array}{l}\text { strategic spatial } \\
\text { planning }\end{array}$ \\
\hline 2 & 0 & territorial cohesion & 5 & 0 & biodiversity \\
\hline 2 & 0 & inequality & 3 & 0 & renewable energy \\
\hline 2 & 0 & $\begin{array}{l}\text { water framework } \\
\text { directive }\end{array}$ & 6 & 0.46 & $\begin{array}{l}\text { ecosystem } \\
\text { approach }\end{array}$ \\
\hline 2 & 0 & Slovenia & 3 & 0 & indicator \\
\hline 29 & 0.05 & $\begin{array}{l}\text { maritime spatial } \\
\text { planning }\end{array}$ & 3 & 0 & $\begin{array}{l}\text { collaborative } \\
\text { planning }\end{array}$ \\
\hline 27 & 0.29 & ecosystem service & 3 & 0.1 & $\begin{array}{l}\text { stakeholder } \\
\text { participation }\end{array}$ \\
\hline 16 & 0.05 & green infrastructure & 3 & 0 & $\begin{array}{c}\text { marine protected } \\
\text { area }\end{array}$ \\
\hline 16 & 0.15 & governance & 15 & 0.1 & $\begin{array}{c}\text { sustainable } \\
\text { development }\end{array}$ \\
\hline 8 & 0 & spatial planning & 8 & 0 & China \\
\hline 6 & 0.1 & sustainability & 4 & 0 & decision-making \\
\hline 4 & 0 & Portugal & 2 & 0.15 & mitigation \\
\hline
\end{tabular}




\subsubsection{Timeline Visualization (WOSCC)}

By combining the co-cited keyword clusters with the timeline (Figure 10), the time span formed by the keyword clusters can be seen more clearly. For example, marine spatial planning started early, but after 2013, the research center of spatial planning gradually shifted. The application of GIS technology has been widely used; GI and stakeholder participation has been more concentrated at a particular time, while the discussion on spatial planning in China has continued since 2008-2009.

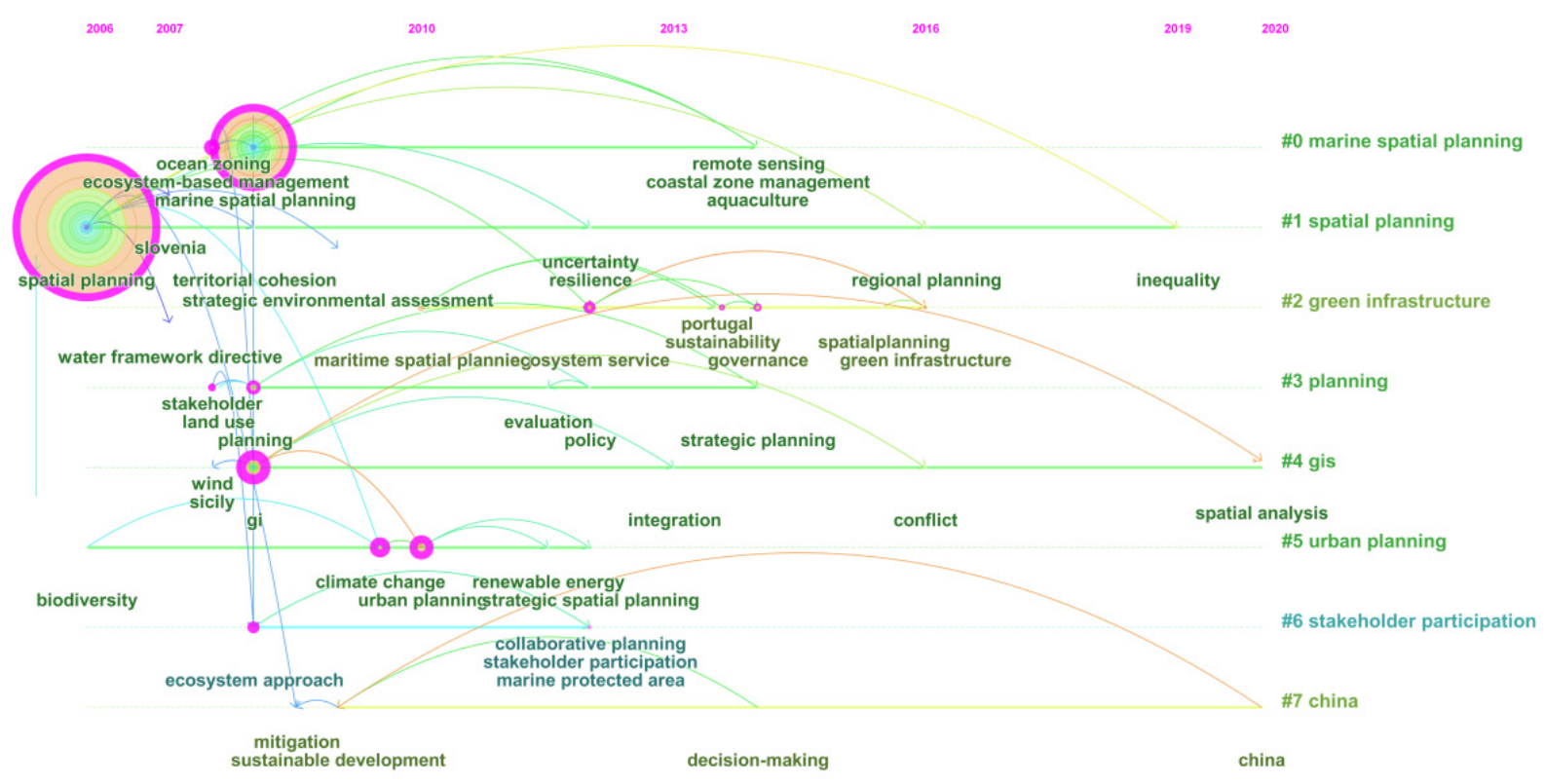

Figure 10. Visualization of the timeline (WOSCC).

\subsection{CNKI Database}

After analyzing the WOSCC, it was found that there is a large gap between the research on spatial planning in developed and developing countries. China is the largest developing country and the only developing country in the country collaboration network shown in Figure 9. In addition, China has formed a separate cluster in recent years, indicating that the research contribution of Chinese institutions and researchers has increased in this field. $\mathrm{CNKI}$ is the largest database of Chinese academic journals, which can supplement research in related fields from China's perspective and help find its unique position, providing a reference for other developing countries.

\subsubsection{Co-Citation Analysis (CNKI Database)}

Through visual analysis of literature published in the CNKI database from 2006 to 2021, several keyword clusters were formed, including studies on policy and management, such as spatial planning, underground space, special planning, space governance, integration of multiple planning, and ecological civilization (Figure 11).

Existing spatial planning faced several challenges due to overly complicated spatial planning systems $[114,115]$. The space was divided into four categories: urban and rural planning, overall land use planning, main function area planning, and ecological function area planning [116]. The consistency among these programs can provide good support for their functioning [117]. Therefore, the current research on spatial planning in China mainly focuses on the establishment of a spatial planning system that integrates multiple plans [118]. 


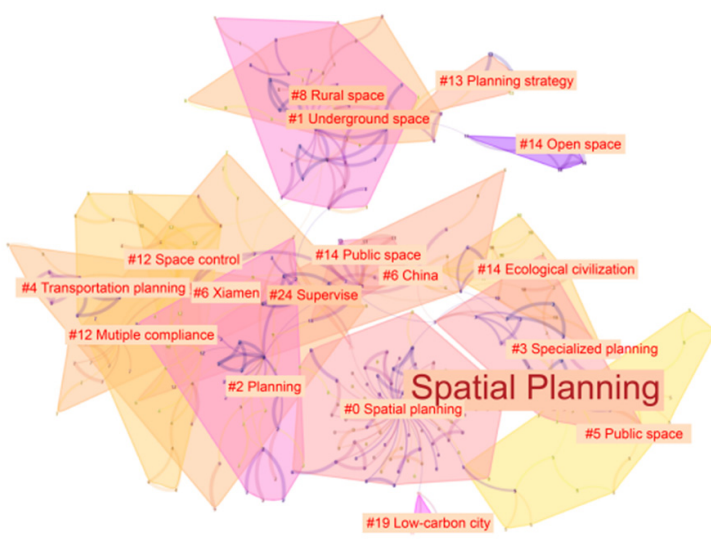

(a)

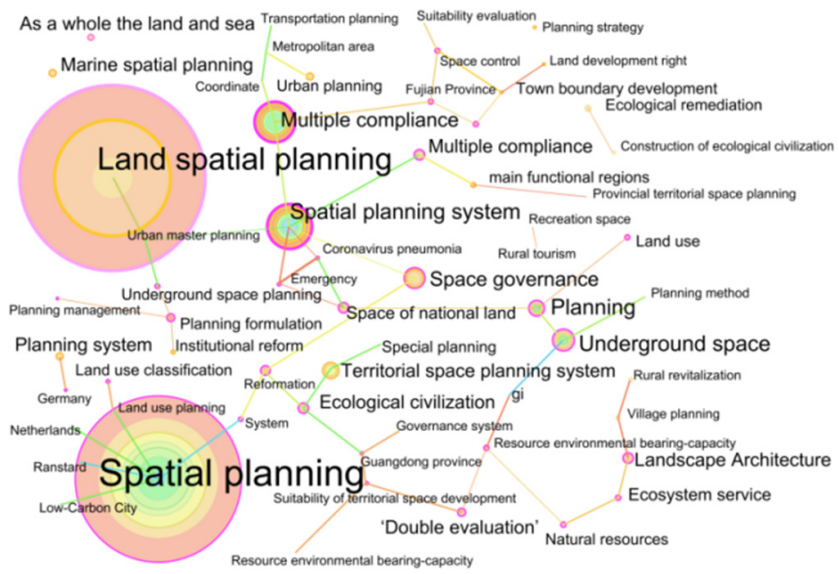

(b)

Figure 11. Visualization of clusters (a) and keyword analysis (b) (CNKI database).

\subsubsection{Author Analysis (CNKI Database)}

The core of the Chinese research team is Min Zhao, Jian Lin, Yumei Cai, and others (Figure 12).

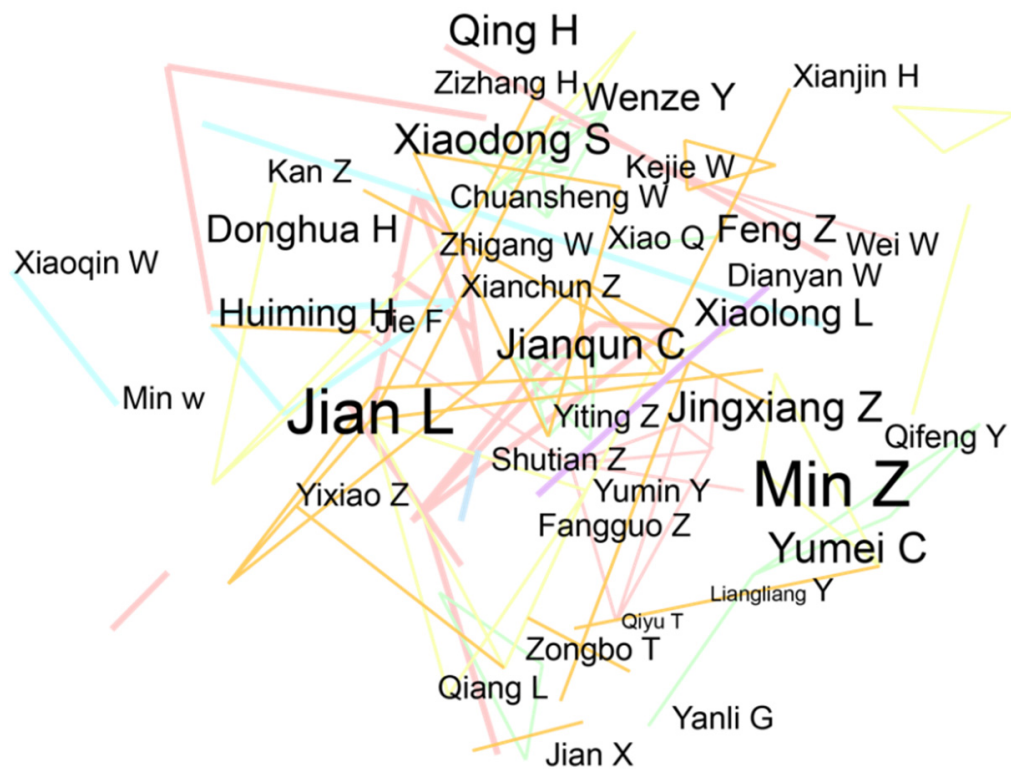

Figure 12. Visualization of the authors' network (CNKI database).

Lin et al. discussed the relationship development and trend between the central and local governments, the market and the government, as well as the method of land and sea coordination in the evolution of spatial planning systems $[119,120]$.

Zhao et al. discussed the concept and strategy of an urban development boundary under a territorial spatial planning system, discussed the coordinated operation strategy of "development planning" and "spatial planning", solved the construction of the land use classification standard system of territorial spatial planning [121,122], and studied the European experience of marine spatial planning from the perspective of land and sea integration [123].

Cai et al. summarized the evolution and inspiration of the spatial planning system in Germany, Finland, the Netherlands, France, the United States, and other developed countries [124], as well as reviewed the domestic spatial planning operation system and spatial planning research at the village scale [125]. 
Chinese researchers are currently studying the evolution of spatial planning systems in other countries and summarizing their experience, while the construction of spatial planning systems at the national level is of greater concern.

\subsubsection{Timeline Visualization (CNKI Database)}

China's development issues can serve as a reference for many developing countries as they was divided into several different periods. It can be seen from the time series that spatial planning research in China is closely related to national policies (Figure 13).

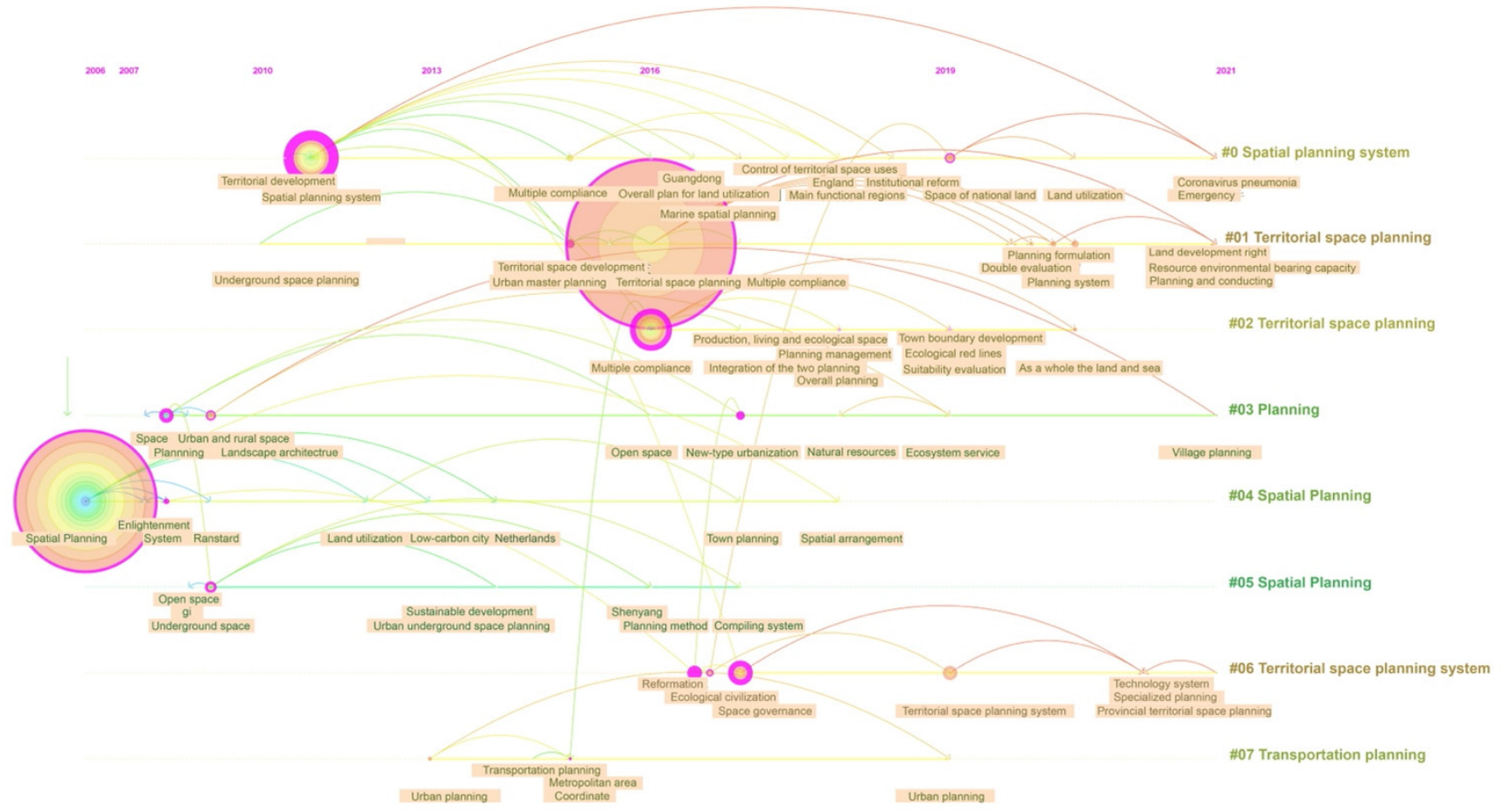

Figure 13. Visualization of the timeline (CNKI database).

In the early stages, China mainly studied the experiences of other countries or regions, especially the developed countries, such as the Netherlands [126], France [127], the United States [128], the European Union [129,130], and the United Kingdom [131], and conducted retrospection and reflection of domestic and foreign development and bibliometric analysis [6,7,132-135].

During the development period, China's spatial planning was paralleled by economic and social development planning, urban and rural planning, and land use planning. In 2018, the Chinese government established the Ministry of Natural Resources, ending the "coexistence of multiple planning" of many years, and striving to achieve "one level of government, one plan, one blueprint". Sectoral coordination is difficult in the early stages, and spatial planning must deal with trade-offs between the desires and needs of various stakeholders [136,137].

Then, the government proposed carrying out ecological civilization construction [138] based on ecosystem climate change and reducing carbon emissions and energy consumption, establishing "three zones and three lines" of ecological protection $[139,140]$, protecting basic farmland and natural resources [141], and improving the environmental carrying capacity [142,143]. Integrating landscape ecology with spatial development planning helps to overcome the complex problems of landscape and natural resource management and increases the chances of achieving sustainable development [144].

Overall, the plan mainly focused on the construction of various levels of the territorial spatial planning system, overall land and sea planning [145], land use classification [146], urban development boundary, and other issues [147]. 


\subsection{Comparison of Burst Keywords}

Burst keywords refer to the acceleration of keyword frequency appearing in a certain period, which can reflect the research focus or new research trends in the period. By summarizing the global and Chinese primary burst keywords, we can explore the current hotspots and trends in the field of spatial planning research.

The concept of spatial planning and sustainable development received attention from an early stage and focused on GI; however, 2018-2019 continues to receive special attention (Figure 14).

Top 20 Keywords with the Strongest Citation Bursts(WOS core collection)

\begin{tabular}{llrlll}
\multicolumn{1}{c}{ Keywords } & \multicolumn{3}{c}{ Year } & Strength Begin & End \\
spatial planning & 2006 & 2.7714 & $\mathbf{2 0 0 6}$ & 2007 \\
strategic environmental assessment & 2006 & 2.3945 & $\mathbf{2 0 0 9}$ & 2015 \\
connectivity & 2006 & 2.4952 & $\mathbf{2 0 1 0}$ & 2011 \\
sustainability & 2006 & 0.984 & $\mathbf{2 0 1 1}$ & 2012 \\
land use planning & 2006 & 2.4294 & $\mathbf{2 0 1 1}$ & 2013 \\
integration & 2006 & 2.4294 & $\mathbf{2 0 1 1}$ & 2013 \\
policy & 2006 & 3.2594 & $\mathbf{2 0 1 1}$ & 2014 \\
ecosystem-based management & 2006 & 2.6941 & $\mathbf{2 0 1 2}$ & 2013 \\
strategic spatial planning & 2006 & 3.8032 & $\mathbf{2 0 1 5}$ & 2016 \\
strategic planning & 2006 & 2.348 & $\mathbf{2 0 1 5}$ & 2016 \\
spatialplanning & 2006 & 3.3351 & $\mathbf{2 0 1 6}$ & 2019 \\
regional planning & 2006 & 3.4269 & $\mathbf{2 0 1 6}$ & 2018 \\
conflict & 2006 & 2.9328 & $\mathbf{2 0 1 6}$ & 2018 \\
participation & 2006 & 1.8783 & $\mathbf{2 0 1 7}$ & 2018 \\
ecosystem service & 2006 & 2.4388 & $\mathbf{2 0 1 7}$ & 2021 \\
climate change & 2006 & 0.9833 & $\mathbf{2 0 1 7}$ & 2018 \\
green infrastructure & 2006 & 3.8873 & $\mathbf{2 0 1 7}$ & 2021 \\
gi & 2006 & 1.2848 & $\mathbf{2 0 1 8}$ & 2019 \\
inequality & 2006 & 1.3561 & $\mathbf{2 0 1 8}$ & 2019 \\
\hline land use & 2006 & 1.3256 & $\mathbf{2 0 1 8}$ & 2019 \\
\hline
\end{tabular}

(a)
Top 20 Keywords with the Strongest Citation Bursts(CNKI database)

\begin{tabular}{|c|c|c|c|c|c|}
\hline Keywords & Year & Strength & Begin & End & $2006-2021$ \\
\hline plan & 2006 & 5.59 & 2006 & 2010 & \\
\hline gi & 2006 & 2.26 & 2007 & 2009 & \\
\hline low-carbon city & 2006 & 2.33 & 2008 & 2013 & \\
\hline wide open space & 2006 & 1.82 & 2008 & 2009 & \\
\hline enlightenment & 2006 & 1.52 & 2008 & 2015 & \\
\hline three dimensions & 2006 & 1.21 & 2008 & 2009 & \\
\hline urban and rural space & 2006 & 1.52 & 2009 & 2013 & \\
\hline metropolitan region & 2006 & 1.22 & 2009 & 2010 & \\
\hline open space & 2006 & 1.65 & 2014 & 2016 & \\
\hline integration of multiple plans & 2006 & 1.44 & 2014 & 2017 & \\
\hline coordinate & 2006 & 2.41 & 2015 & 2017 & \\
\hline metropolitan area & 2006 & 1.72 & 2015 & 2018 & \\
\hline public space & 2006 & 1.61 & 2015 & 2018 & \\
\hline integration of multiple plans & 2006 & 7.23 & 2016 & 2017 & \\
\hline reform & 2006 & 2.15 & 2017 & 2018 & \\
\hline surbey design & 2006 & 1.22 & 2017 & 2019 & \\
\hline three areas, three line & 2006 & 1.22 & 2017 & 2019 & \\
\hline planning management & 2006 & 1.26 & 2018 & 2021 & \\
\hline space of national land & 2006 & 3 & 2019 & 2021 & \\
\hline ecological civilization & 2006 & 2.72 & 2019 & 2021 & \\
\hline
\end{tabular}

(b)

Figure 14. Visualization of the top twenty keywords with the strongest citation burst words for the WOSCC (a) and the CNKI database (b).

From China's perspective, we can see that after the policy reform, the professional field of landscape architecture focused more on spatial planning, and social development and policymaking placed greater emphasis on ecological civilization construction. In addition to the conventional GIS as the technical means of spatial planning, the present research combined with more information tools can perform more quantitative analysis and measurement.

\section{Discussion}

Knowledge maps help us clearly review previous studies and forecast future development directions. The tool which helps make knowledge maps, such as CiteSpace, is used by many researchers around the world at present in various fields such as agriculture [148], food science [149,150], technology [151-155], planning [156-159], tourism [160], energies [161,162], medicine [163,164], health [165,166], ecology [167-171], and so on [172-174]. As an important tool for sustainable development, spatial planning has undoubtedly attracted the attention of many countries. Relevant research focuses on building spatial planning systems, building blue-green infrastructure, enhancing public participation and justice, and other initiatives. Spatial planning will have a different emphasis because of the different development stages in each country. A visual analysis of the literature can help us see the differences more clearly.

Taking China as an example, we can see the uniqueness of a country more clearly. Although the keywords used in Chinese literature correspond to the English word spatial 
planning, and the definition is also used internationally, spatial planning in China generally refers to the long-term planning and overall layout of land resources and spatial distribution within the jurisdiction of a national or regional government to achieve effective control, scientific management of territorial space, and promote the balance between development and protection. It is widely recognized as an effective tool for promoting spatial governance and sustainable regional development [175]. China's previous spatial planning had limited land use efficiency in terms of spatial efficiency and industrial structure [176]. In addition, in the investigation and evaluation of natural resource assets, there were problems such as unclear ownership boundaries, unclear division of rights and responsibilities, difficulty in measuring values, and extensive utilization of various natural resources [177]. This reflects differences in the research objectives of specific countries on issues related to spatial planning.

Meanwhile, there are still some limitations. For example, although WOSCC and CNKI databases are representative databases in the world and China, their evaluation criteria may not fully reflect the value and real influence of their research, as WOSCC is more representative for hard science, while social sciences and humanities' scientific branches are less represented [39]. Meanwhile, some influential scholars in their own countries may publish mainly in their own countries' journals or magazines, especially in other developing countries and non-native English-speaking countries, and only the CNKI database has been selected as the representative here. Secondly, the principle of "broad general keywords search strategy" proposed by Dr. Chen may not cover all literature in the field of spatial planning, and there may be omissions. In addition, although we have conducted preliminary screening and removed the literature in unrelated fields, there is still some irrelevant literature that cannot be removed by preliminary means.

\section{Conclusions and Prospects}

In this study, CiteSpace was used to conduct a visual knowledge map analysis of literature on global spatial planning and China from 2006 to 2021. The following conclusions can be drawn:

1. The number of papers published in global spatial planning research shows an increasing trend, while China starts many years later but develops rapidly, and its international influence increases rapidly. Especially after 2018, the number of papers shows an obvious increasing trend, which is coincident with the implementation of national policies.

2. Globally, the United States has the largest number of relevant research results; the United Kingdom, Germany, New Zealand, and other countries have also published many studies, and Italy has the most cooperation with other countries. Different countries have different emphases on spatial planning research due to different national conditions and development stages. Developed countries have higher research levels and closer cooperation while developing countries are relatively weak and vulnerable to natural disasters and climate. However, China has developed rapidly in recent years and has gradually increased its influence.

3. Disciplines such as environmental science and ecology, public administration, and regional and urban planning pay more attention to spatial planning. There is some cooperation between disciplines, but it is not very close.

4. Globally, Stead D, Calado H, Gee K, and Jay S were key contributors. China has formed a research team with Jian Lin and Min Zhao as the core, which currently focuses on the discussion of territorial space planning and the idea of coordinated development of land and sea. Yumei Cai and others reviewed the spatial planning policies and experiences of developed countries and regions. However, the collaboration among authors is not strong enough, either internationally or in China.

5. Through keyword cluster, timeline, and time zone analysis, global development can be roughly divided into three stages: The first stage is characterized by the study of spatial planning system theory, the second stage is characterized by building green 
infrastructure and providing ecological services, and the third stage is characterized by an emphasis on public participation and the establishment of equitable mechanisms. China's development corresponds to three stages: the first stage is the theory and experience learning stage of developed countries, the second stage is the function establishment stage of the spatial planning system focusing on economic development, and the third stage is the integration of multiple plans and a sustainable development exploration stage.

6. There are differences in burst words between the world and China, indicating that there are great differences in research hotspots in different countries' periods and conditions.

In summary, this study further analyzes and summarizes the research results of spatial planning, to reveal the dynamics, development process, and evolution of spatial planning research objectively, uncover the frontiers and hotspots of spatial planning theory and practice research, and provide a scientific reference for new research. Meanwhile, it can be seen from the analysis that exchanges and cooperation in this field are still lacking at present. Therefore, more extensive exchange and cooperation platforms should be established in the future to promote cooperation between countries, research institutions, and researchers.

Global spatial planning is dominated by developed countries, so the research focus is no longer on the construction of spatial planning systems, since the system construction has been relatively mature, and the focus has shifted to the study of climate, green infrastructure, participatory planning, and justice mechanisms. Meanwhile, China's current research focuses still on the administrative system, which is relatively backward. However, both the world and China can provide references for other developing countries in different historical periods or development stages. However, different countries have different situations, so spatial planning will involve different national conditions of each country. Previous studies mainly used a single database as the data source, which may lead to this situation being ignored.

Both developed and developing countries have the responsibility and obligation to work together for sustainable development, and it is a macro, overall, and systematic complex project that needs to build a reasonable spatial planning system, which requires joint wisdom, participation, efforts of planners, policymakers, and citizens around the world.

Therefore, future studies should focus more on exchanges between developed and developing countries, pay attention to the construction of spatial planning systems in developing countries, and comprehensively consider the world as a community with a shared future. At the same time, with respect to different development situations of different countries, developed countries can introduce their experience to developing countries more. Developing countries should be given more platforms or attention due to their weak academic research strength. Thus, based on the SDGs, establishing and working on global spatial planning strategies integrating developed and developing countries should be further studied.

Author Contributions: Conceptualization, J.Z.; Data curation, J.Z. and Q.W.; Funding acquisition, J.Z.; Methodology, J.Z., Q.W., Y.X. and K.F.; Software, J.Z. and Q.W.; Supervision, K.F.; Visualization, J.Z.; Writing—original draft, J.Z.; Writing—review and editing, J.Z., Q.W. and K.F. All authors have read and agreed to the published version of the manuscript.

Funding: The first author gratefully acknowledges financial support from the China Scholarship Council (202008330384).

Institutional Review Board Statement: Not applicable.

Informed Consent Statement: Not applicable.

Data Availability Statement: Not applicable.

Acknowledgments: The authors would like to thank the reviewers and the editor whose suggestions greatly improved the manuscript.

Conflicts of Interest: The authors declare no conflict of interest. 


\section{References}

1. Patrizzi, N.S.; Dobrovolski, R. Integrating climate change and human impacts into marine spatial planning: A case study of threatened starfish species in Brazil. Ocean. Coast. Manag. 2018, 161, 177-188. [CrossRef]

2. Shekhar, H.; Schmidt, A.J.; Wehling, H.-W. Exploring wellbeing in human settlements-A spatial planning perspective. Habitat Int. 2019, 87, 66-74. [CrossRef]

3. Zhang, X.; Zhao, Y.; Jin, F.; Sun, W. Tracking hot spots of sustainable development research in domestic and foreign literature in the past twenty-five years: Bibliometric analysis based on CiteSpace. J. Univ. Chin. Acad. Sci. 2022, $39,8$.

4. Fischer, T.B.; Muthoora, T.; Chang, M.; Sharpe, C. Health impact assessment in spatial planning in Englan-Types of application and quality of documentation. Environ. Impact Assess. Rev. 2021, 90, 106631. [CrossRef]

5. Wiehe, J.; von Haaren, C.; Walter, A. How to achieve the climate targets? Spatial planning in the context of the German energy transition. Energy Sustain. Soc. 2020, 10, 10. [CrossRef]

6. Zhang, Y.; Zhang, X.; Hu, Y. A review of spatial planning theory and practice at home and abroad. J. Anhui Jianzhu Univ. 2019, 27, 29-35.

7. Luo, C.; Wang, G.; Sun, L. Research Review of Spatial Planning Development and Reform in China and Abroad. Urban Plan. Int. 2018, 33, 117.

8. Högström, J.; Brokking, P.; Balfors, B.; Hammer, M. Approaching Sustainability in Local Spatial Planning Processes: A Case Study in the Stockholm Region, Sweden. Sustainability 2021, 13, 2601. [CrossRef]

9. Nogués, S.; González-González, E.; Cordera, R. Planning regional sustainability: An index-based framework to assess spatial plans. Application to the region of Cantabria (Spain). J. Clean. Prod. 2019, 225, 510-523. [CrossRef]

10. Gao, Z.; Tan, N.; Geddes, R.R.; Ma, T. Population Distribution Characteristics and Spatial Planning Response Analysis in Metropolises: A Case Study of Beijing. Int. Rev. Spat. Plan. Sustain. Dev. 2018, 7, 134-154. [CrossRef]

11. Ran, J.; Nedovic-Budic, Z. Designing an Information Infrastructure for Policy Integration of Spatial Planning and Flood Risk Management. Int. J. E-Plan. Res. 2018, 7, 53-85. [CrossRef]

12. Mustafa, A.; Bruwier, M.; Archambeau, P.; Erpicum, S.; Pirotton, M.; Dewals, B.; Teller, J. Effects of spatial planning on future flood risks in urban environments. J. Environ. Manag. 2018, 225, 193-204. [CrossRef]

13. Sagala, S.A.H.; Suroso, D.S.A.; Puspitasari, N.; Suroso, A.A.; Rizqika, K.A. Knowledge and implementation gaps in disaster risk reduction and spatial planning: Palu City, Indonesia. Disaster Prev. Manag. Int. J. 2021, 30, 462-479. [CrossRef]

14. Gustafsson, S.; Hermelin, B.; Smas, L. Integrating environmental sustainability into strategic spatial planning: The importance of management. J. Environ. Plan. Manag. 2018, 62, 1321-1338. [CrossRef]

15. Busayo, E.T.; Kalumba, A.M.; Orimoloye, I.R. Spatial planning and climate change adaptation assessment: Perspectives from Mdantsane Township dwellers in South Africa. Habitat Int. 2019, 90, 101978. [CrossRef]

16. Solly, A. Land use challenges, sustainability and the spatial planning balancing act: Insights from Sweden and Switzerland. Eur. Plan. Stud. 2020, 29, 637-653. [CrossRef]

17. Lüer, C.; Böhme, K. Reenergizing European Spatial Planning. Plan. Pract. Res. 2020, 1-15. [CrossRef]

18. Chen, Y.; Xing, X.; Cheng, D.; Xue, Y.; Wu, F.; Zhang, D. Construction of national agricultural informatization knowledge graph based on citespace and intermediary centrality algorithm. J. Southwest Minzu Univ. 2022, 48, 7.

19. Zheng, Z.; Liu, Y.; Zhang, Y.; Wen, C. TCMKG: A Deep Learning Based Traditional Chinese Medicine Knowledge Graph Platform. In Proceedings of the 2020 IEEE International Conference on Knowledge Graph (ICKG), Nanjing, China, 9-11 August 2020; pp. 560-564.

20. Cheng, B.; Guan, X.; Xiang, L. A Conceptual Data Model for Dynamic Changes Expression of Spatio-temporal Object and Its Association. J. Geo-Inf. Sci. 2017, 19, 1415-1421.

21. Lv, T.; Wang, L.; Xie, H.; Zhang, X.; Zhang, Y. Exploring the Global Research Trends of Land Use Planning Based on a Bibliometric Analysis: Current Status and Future Prospects. Land 2021, 10, 304. [CrossRef]

22. Pan, X.; Yan, E.; Cui, M.; Hua, W. Examining the usage, citation, and diffusion patterns of bibliometric mapping software: A comparative study of three tools. J. Informetr. 2018, 12, 481-493. [CrossRef]

23. Chen, Y.; Chen, C.M.; Liu, Z.Y.; Hu, Z.G.; Wang, X.W. The methodology function of CiteSpace mapping knowledge domains. Stud. Sci. Sci. 2015, 33, 242-253.

24. Azam, A.; Ahmed, A.; Kamran, M.S.; Hai, L.; Zhang, Z.; Ali, A. Knowledge structuring for enhancing mechanical energy harvesting (MEH): An in-depth review from 2000 to 2020 using CiteSpace. Renew. Sustain. Energy Rev. 2021, 150, 111460. [CrossRef]

25. Carve, M.; Allinson, G.; Nugegoda, D.; Shimeta, J. Trends in environmental and toxicity research on organic ultraviolet filters: A scientometric review. Sci. Total Environ. 2021, 773, 145628. [CrossRef]

26. de Castilhos Ghisi, N.; Zuanazzi, N.R.; Fabrin, T.M.C.; Oliveira, E.C. Glyphosate and its toxicology: A scientometric review. Sci. Total Environ. 2020, 733, 139359. [CrossRef]

27. Azam, A.; Ahmed, A.; Wang, H.; Wang, Y.; Zhang, Z. Knowledge structure and research progress in wind power generation (WPG) from 2005 to 2020 using CiteSpace based scientometric analysis. J. Clean. Prod. 2021, 295, 126496. [CrossRef]

28. Daim, T.; Lai, K.K.; Yalcin, H.; Alsoubie, F.; Kumar, V. Forecasting technological positioning through technology knowledge redundancy: Patent citation analysis of IoT, cybersecurity, and Blockchain. Technol. Forecast. Soc. Chang. 2020, 161, 120329. [CrossRef] 
29. Pestana, M.H.; Sánchez, A.V.; Moutinho, L. The network science approach in determining the intellectual structure, emerging trends and future research opportunities-An application to senior tourism research. Tour. Manag. Perspect. 2019, 31, 370-382. [CrossRef]

30. Yilmaz, Y.; Seyis, S. Mapping the scientific research of the life cycle assessment in the construction industry: A scientometric analysis. Build. Environ. 2021, 204, 108086. [CrossRef]

31. Obringer, R.; Nateghi, R. What makes a city 'smart' in the Anthropocene? A critical review of smart cities under climate change. Sustain. Cities Soc. 2021, 75, 103278. [CrossRef]

32. Liu, C.; Yang, R.J.; Yu, X.; Sun, C.; Wong, P.S.; Zhao, H. Virtual power plants for a sustainable urban future. Sustain. Cities Soc. 2021, 65, 102640. [CrossRef]

33. Carollo, A.; Bonassi, A.; Lim, M.; Gabrieli, G.; Setoh, P.; Dimitriou, D.; Aryadoust, V.; Esposito, G. Developmental disabilities across the world: A scientometric review from 1936 to 2020. Res. Dev. Disabil. 2021, 117, 104031. [CrossRef] [PubMed]

34. Picone, F.; Buonocore, E.; Chemello, R.; Russo, G.; Franzese, P. Exploring the development of scientific research on Marine Protected Areas: From conservation to global ocean sustainability. Ecol. Inform. 2021, 61, 101200. [CrossRef]

35. Morar, M.; Agachi, P.S. Review: Important contributions in development and improvement of the heat integration techniques. Comput. Chem. Eng. 2010, 34, 1171-1179. [CrossRef]

36. Zhou, W.; Yuan, J. A Review of Rural Spatial Governance Based on CiteSpace. 2021. Available online: https://kns.cnki.net/ kcms / detail / detail.aspx?dbcode=CPFD\&dbname=CPFDLAST2021\&filename=ZHCG202109016098\&uniplatform=NZKPT\& v=1KsIT9Fqm86YYMrXEzIlkMLZqijn_b32CsiaQWQhjNNiKSGE9fjYQgbT6pRpHZZ09ZX4h1p_n0w\%3d (accessed on 10 December 2021).

37. Wang, Y.; Xu, J. Knowledge Mapping of Rural Governance System Research: Based on CiteSpace Visualization Analysis. J. Manag. Cadre Coll. Minist. Agric. Rural. Aff. 2021, 45, 6.

38. Luo, J.; Xu, Z.; Chen, C. A Research Review of Rural Public Space in China Based on CiteSpace. 2021. Available online: https:/ / www.aisoutu.com/a/1500247 (accessed on 10 December 2021).

39. Chen, K.-H.; Tang, M.-C.; Wang, C.-M.; Hsiang, J. Exploring alternative metrics of scholarly performance in the social sciences and humanities in Taiwan. Scientometrics 2014, 102, 97-112. [CrossRef]

40. Chen, L.; Wang, H.; Wang, J. The Current Situation and Prospects of Carbon Neutral Bibliometric Analysis Based on CiteSpace. For. Econ. 2021, 12, 56-61.

41. Chen, C. Science Mapping: A Systematic Review of the Literature. J. Data Inf. Sci. 2017, 2, 1-40. [CrossRef]

42. Sood, S.; Rawat, K.; Sharma, G. 3-D Printing Technologies From Infancy to Recent Times: A Scientometric Review. IEEE Trans. Eng. Manag. 2022,1-17. [CrossRef]

43. Hersperger, A.M.; Grădinaru, S.; Oliveira, E.; Pagliarin, S.; Palka, G. Understanding strategic spatial planning to effectively guide development of urban regions. Cities 2019, 94, 96-105. [CrossRef]

44. Zonneveld, W. CRONWE: First attempts to institutionalize European spatial planning. Plan. Perspect. 2018, 33, 523-542. [CrossRef]

45. Bafarasat, A.Z.; Oliveira, E. Disentangling three decades of strategic spatial planning in England through participation, project promotion and policy integration. Eur. Plan. Stud. 2020, 29, 1375-1392. [CrossRef]

46. Marshall, T. Infrastructure planning and spatial planning: Current relationships in the UK. Town Plan. Rev. 2020, 91, 47-69. [CrossRef]

47. Ustaoglu, E.; Koomen, E.; Rouwendal, J. Urban density and spatial planning: The unforeseen impacts of Dutch devolution. PLoS ONE 2020, 15, e0240738.

48. Christmann, G.B.; Ibert, O.; Jessen, J.; Walther, U.J. Innovations in spatial planning as a social process-Phases, actors, conflicts. Eur. Plan. Stud. 2019, 28, 496-520. [CrossRef]

49. Diller, C.; Hoffmann, A.; Oberding, S. Rational Versus Communicative: Towards an Understanding of Spatial Planning Methods in German Planning Practice. Plan. Pract. Res. 2018, 33, 244-263. [CrossRef]

50. A review of the academic reports of Shanghai International Symposium on Space and Future. Shanghai Land Resour. 2018, 40, 1-8.

51. Humer, A. Linking polycentricity concepts to periphery: Implications for an integrative Austrian strategic spatial planning practice. Eur. Plan. Stud. 2017, 26, 635-652. [CrossRef]

52. Lityński, P.; Hołuj, A. Urban Sprawl Risk Delimitation: The Concept for Spatial Planning Policy in Poland. Sustainability 2020, 12, 2637. [CrossRef]

53. Batunova, E.; Gunko, M. Urban shrinkage: An unspoken challenge of spatial planning in Russian small and medium-sized cities. Eur. Plan. Stud. 2018, 26, 1580-1597. [CrossRef]

54. Cilliers, E. Reflecting on Green Infrastructure and Spatial Planning in Africa: The Complexities, Perceptions, and Way Forward. Sustainability 2019, 11, 455. [CrossRef]

55. Horn, A. The Darker Side of Muddling Through: An Analysis of Spatial Planning Policy Decision-Making and Policy Termination in Cape Town, South Africa. Urban Forum 2020, 31, 573-598. [CrossRef]

56. Chigudu, A.; Chirisa, I. The quest for a sustainable spatial planning framework in Zimbabwe and Zambia. Land Use Policy 2020, 92, 104442. [CrossRef]

57. Rachmawati, R. Urban Development, Land Use, and Spatial Planning for Settlements: Lessons Learned from Yogyakarta City, Indonesia. Am. J. Econ. Sociol. 2021, 80, 757-775. [CrossRef] 
58. Mosso, C.E.; Hostetler, M.; Ecobedo, F.J. Urban expansion into native forests in Patagonia, Argentina: Assessing stakeholders' perceptions regarding spatial planning. J. Environ. Plan. Manag. 2020, 64, 774-795. [CrossRef]

59. Peker, E.; Orhan, E. Mekânsal Planlamada Deprem Riski ve İklim Krizini Birlikte Ele Almak. J. Plan. 2021, 31, $288-301$.

60. Sulistyawan, B.S.; Verweij, P.A.; Boot, R.G.A.; Purwanti, B.; Rumbiak, W.; Wattimena, M.C.; Rahawarin, P.; Adzan, G. Integrating participatory GIS into spatial planning regulation: The case of Merauke District, Papua, Indonesia. Int. J. Commons 2018, 12, 25-59. [CrossRef]

61. Dhiman, R.; Kalbar, P.; Inamdar, A.B. Spatial planning of coastal urban areas in India: Current practice versus quantitative approach. Ocean. Coast. Manag. 2019, 182, 104929. [CrossRef]

62. Chen, C.; Ibekwe-SanJuan, F.; Hou, J. The structure and dynamics of cocitation clusters: A multiple-perspective cocitation analysis. J. Am. Soc. Inf. Sci. Technol. 2010, 61, 1386-1409. [CrossRef]

63. Pezzagno, M.; Richiedei, A.; Tira, M. Spatial Planning Policy for Sustainability: Analysis Connecting Land Use and GHG Emission in Rural Areas. Sustainability 2020, 12, 947. [CrossRef]

64. Monk, J. Finisterra Annual Lecture: Placing gender in geography, directions, challenges, and opportunities. Finisterra 2018, 53, 3-14. [CrossRef]

65. Zhang, H.; Peng, J.; Wang, R.; Zhang, J.; Yu, D. Spatial planning factors that influence $\mathrm{CO}_{2}$ emissions: A systematic literature review. Urban Clim. 2021, 36, 100809. [CrossRef]

66. Thoidou, E. Spatial Planning and Climate Adaptation: Challenges of Land Protection in a Peri-Urban Area of the Mediterranean City of Thessaloniki. Sustainability 2021, 13, 4456. [CrossRef]

67. Jaligot, R.; Chenal, J. Stakeholders' Perspectives to Support the Integration of Ecosystem Services in Spatial Planning in Switzerland. Environments 2019, 6, 88. [CrossRef]

68. Rozas-Vásquez, D.; Fürst, C.; Geneletti, D. Integrating ecosystem services in spatial planning and strategic environmental assessment: The role of the cascade model. Environ. Impact Assess. Rev. 2019, 78, 106291. [CrossRef]

69. Scott, A.; Carter, C.; Hardman, M.; Grayson, N.; Slaney, T. Mainstreaming ecosystem science in spatial planning practice: Exploiting a hybrid opportunity space. Land Use Policy 2018, 70, 232-246. [CrossRef]

70. Meerow, S. A green infrastructure spatial planning model for evaluating ecosystem service tradeoffs and synergies across three coastal megacities. Environ. Res. Lett. 2019, 14, 125011. [CrossRef]

71. Gandarillas, M.Á.; McCall, M.K. Ecocultural networks as grounds for spatial planning. A psychosocial approach applied to coastal development. J. Cult. Herit. Manag. Sustain. Dev. 2021; ahead-of-print.

72. Frederiksen, P.; Morf, A.; von Thenen, M.; Armoskaite, A.; Luhtala, H.; Schiele, K.S.; Strake, S.; Hansen, H.S. Proposing an ecosystem services-based framework to assess sustainability impacts of maritime spatial plans (MSP-SA). Ocean. Coast. Manag. 2021, 208, 105577. [CrossRef]

73. Albert, C.; Fürst, C.; Ring, I.; Sandström, C. Research note: Spatial planning in Europe and Central Asia-Enhancing the consideration of biodiversity and ecosystem services. Landsc. Urban Plan. 2020, 196, 103741. [CrossRef]

74. Vaz, A.S.; Amorim, F.; Pereira, P.; Antunes, S.; Rebelo, H.; Oliveira, N.G. Integrating conservation targets and ecosystem services in landscape spatial planning from Portugal. Landsc. Urban Plan. 2021, 215, 104213. [CrossRef]

75. Asarpota, K.; Nadin, V. Energy Strategies, the Urban Dimension, and Spatial Planning. Energies 2020, 13, 3642. [CrossRef]

76. Stead, D. Conceptualizing the Policy Tools of Spatial Planning. J. Plan. Lit. 2021, 36, 297-311. [CrossRef]

77. Lowe, M.; Whitzman, C.; Giles-Corti, B. Health-Promoting Spatial Planning: Approaches for Strengthening Urban Policy Integration. Plan. Theory Pract. 2017, 19, 180-197. [CrossRef]

78. Sofianto, K.; Nugrahanto, W.; Yuniadi, A.; Falah, M. Morphology of Garut City: Spatial Planning and Transportation System. Anc. Asia 2020, 11, 12. [CrossRef]

79. He, S.Y.; Tao, S.; Ng, M.K.; Tieben, H. Evaluating Hong Kong's Spatial Planning in New Towns From the Perspectives of Job Accessibility, Travel Mobility, and Work-Life Balance. J. Am. Plan. Assoc. 2020, 86, 324-338. [CrossRef]

80. Egidi, G.; Cividino, S.; Quaranta, G.; Alhuseen, A.; Salvati, L. Land mismatches, urban growth and spatial planning: A contribution to metropolitan sustainability. Environ. Impact Assess. Rev. 2020, 84, 106439. [CrossRef]

81. Su, S.; Zhang, J.; He, S.; Zhang, H.; Hu, L.; Kang, M. Unraveling the impact of TOD on housing rental prices and implications on spatial planning: A comparative analysis of five Chinese megacities. Habitat Int. 2021, 107, 102309. [CrossRef]

82. Knickel, K.; Almeida, A.; Bauchinger, L.; Casini, M.; Gassler, B.; Hausegger-Nestelberger, K.; Heley, J.; Henke, R.; Knickel, M.; Oostindie, H.; et al. Towards More Balanced Territorial Relations-The Role (and Limitations) of Spatial Planning as a Governance Approach. Sustainability 2021, 13, 5308. [CrossRef]

83. Gu, K.; Fang, Y.; Qian, Z.; Sun, Z.; Wang, A. Spatial planning for urban ventilation corridors by urban climatology. Ecosyst. Health Sustain. 2020, 6, 1747946. [CrossRef]

84. Brunetta, G.; Ceravolo, R.; Barbieri, C.A.; Borghini, A.; De Carlo, F.; Mela, A.; Beltramo, S.; Longhi, A.; De Lucia, G.; Ferraris, S.; et al. Territorial Resilience: Toward a Proactive Meaning for Spatial Planning. Sustainability 2019, 11, 2286. [CrossRef]

85. Chinis, I.; Pozoukidou, G.; Istoriou, T. Renegotiating spatial planning practices: The role of collective initiatives and informal networks. Eur. Plan. Stud. 2021, 1-18. [CrossRef]

86. Rega, C.; Bonifazi, A. The Rise of Resilience in Spatial Planning: A Journey through Disciplinary Boundaries and Contested Practices. Sustainability 2020, 12, 7277. [CrossRef]

87. Williams, J. The role of spatial planning in transitioning to circular urban development. Urban Geogr. 2020, 41,915-919. [CrossRef] 
88. Hurlimann, A.; Wilson, E. Sustainable Urban Water Management under a Changing Climate: The Role of Spatial Planning. Water 2018, 10, 546. [CrossRef]

89. Kiessling, N.; Pütz, M. Assessing Spatial Planning Outcomes-A Novel Framework Based on Conformance and Governance Capacities. Plan. Theory Pract. 2021, 22, 414-432. [CrossRef]

90. Yang, X.; Sun, W.; Li, P.; Mu, X.; Gao, P.; Zhao, G. Integrating agricultural land, water yield and soil conservation trade-offs into spatial land use planning. Ecol. Indic. 2019, 104, 219-228. [CrossRef]

91. Gourgiotis, A.; Kyvelou, S.; Lainas, I. Industrial Location in Greece: Fostering Green Transition and Synergies between Industrial and Spatial Planning Policies. Land 2021, 10, 271. [CrossRef]

92. Wang, W.; Jiao, L.; Jia, Q.; Liu, J.; Mao, W.; Xu, Z.; Li, W. Land use optimization modelling with ecological priority perspective for large-scale spatial planning. Sustain. Cities Soc. 2021, 65, 102575. [CrossRef]

93. Nunbogu, A.M.; Korah, P.I.; Cobbinah, P.B.; Poku-Boansi, M. Doing it 'ourselves': Civic initiative and self-governance in spatial planning. Cities 2018, 74, 32-41. [CrossRef]

94. Lovrić, N.; Lovrić, M. Network approach to constructing theory of participation in spatial planning. Land Use Policy 2018, 79, 30-47. [CrossRef]

95. Bąkowska-Waldmann, E.; Kaczmarek, T. The Use of PPGIS: Towards Reaching a Meaningful Public Participation in Spatial Planning. ISPRS Int. J. Geo-Inf. 2021, 10, 581. [CrossRef]

96. Haryanto, R.; Buchori, I.; Yuliastuti, N.; Saleh, I.; Sugiri, A.; Nuari, B.; Putri, N. Preparedness to Implement a Spatial Plan: The Impact of the Land Cooperative in Central Bangka Regency. Sustainability 2020, 12, 10665. [CrossRef]

97. Decoville, A. Use and Misuse of Indicators in Spatial Planning: The Example of Land Take. Plan. Pract. Res. 2017, 33, 70-85. [CrossRef]

98. Cotella, G.; Stead, D. Spatial Planning and the Influence of Domestic Actors: Some Conclusions. disP-Plan. Rev. 2012, 47, 77-83. [CrossRef]

99. Dühr, S.; Stead, D.; Zonneveld, W. The Europeanization of spatial planning through territorial cooperation. Plan. Pract. Res. 2007, 22, 291-307. [CrossRef]

100. Nadin, V.; Stead, D. European Spatial Planning Systems, Social Models and Learning. disP-Plan. Rev. 2012, 44, 35-47. [CrossRef]

101. Nadin, V.; Stead, D.; Dabrowski, M.; Fernandez-Maldonado, A.M. Integrated, adaptive and participatory spatial planning: Trends across Europe. Reg. Stud. 2020, 55, 791-803. [CrossRef]

102. Ansong, J.; Calado, H.; Gilliland, P.M. A multifaceted approach to building capacity for marine/maritime spatial planning based on European experience. Mar. Policy 2021, 132, 103422. [CrossRef]

103. Finke, G.; Gee, K.; Kreiner, A.; Amunyela, M.; Braby, R. Namibia's way to Marine Spatial Planning-Using existing practices or instigating its own approach? Mar. Policy 2020, 121, 104107. [CrossRef]

104. Jay, S. Measured as the water flows: The striated and smooth in marine spatial planning. Marit. Stud. 2019, 19, 255-268. [CrossRef]

105. Gilek, M.; Armoskaite, A.; Gee, K.; Saunders, F.; Tafon, R.; Zaucha, J. In search of social sustainability in marine spatial planning: A review of scientific literature published 2005-2020. Ocean. Coast. Manag. 2021, 208, 105618. [CrossRef]

106. Zhang, Y.; Zhang, Z.K.; Zhang, J.; Chen, H. Research progress of Marine space planning in European and American countries. Mar. Sci. Bull. 2013, 32, 352-360.

107. Maragno, D.; Dall'Omo, C.F.; Pozzer, G.; Bassan, N.; Musco, F. Land-Sea Interaction: Integrating Climate Adaptation Planning and Maritime Spatial Planning in the North Adriatic Basin. Sustainability 2020, 12, 5319. [CrossRef]

108. Chalastani, V.I.; Tsoukala, V.K.; Coccossis, H.; Duarte, C.M. A bibliometric assessment of progress in marine spatial planning. Mar. Policy 2021, 127, 104329. [CrossRef]

109. Krämer, L. The eu Directive 2014/89 Establishing a Framework for Maritime Spatial Planning. J. Eur. Environ. Plan. Law 2018, 15, 24-41. [CrossRef]

110. Seiwert, A.; Rößler, S. Understanding the term green infrastructure: Origins, rationales, semantic content and purposes as well as its relevance for application in spatial planning. Land Use Policy 2020, 97, 104785. [CrossRef]

111. García, A.M.; Santé, I.; Loureiro, X.; Miranda, D. Green infrastructure spatial planning considering ecosystem services assessment and trade-off analysis. Application at landscape scale in Galicia region (NW Spain). Ecosyst. Serv. 2020, 43, 101115. [CrossRef]

112. Ronchi, S.; Arcidiacono, A.; Pogliani, L. Integrating green infrastructure into spatial planning regulations to improve the performance of urban ecosystems. Insights from an Italian case study. Sustain. Cities Soc. 2020, 53, 101907. [CrossRef]

113. García, A.M.; Santé, I.; Loureiro, X.; Miranda, D. Spatial Planning of Green Infrastructure for Mitigation and Adaptation to Climate Change at a Regional Scale. Sustainability 2020, 12, 10525. [CrossRef]

114. Bai, J.; Huang, K.; Lu, Y. The cognition of the core value of territorial spatial planning system and its determination strategy. Planners 2021, 37, 12-19.

115. Wang, X.; Liu, W. China's spatial planning system: Present situation, Problems and Reconstruction. Econ. Geogr. 2012, 32, 7-15.

116. Lin, J.; Chen, S.H.; Xu, C.; Wang, C. Game analysis of spatial planning. J. Urban Plan. 2015, 1, 10-14.

117. Bacău, S.; Grădinaru, S.R.; Hersperger, A.M. Spatial plans as relational data: Using social network analysis to assess consistency among Bucharest's planning instruments. Land Use Policy 2020, 92, 104484. [CrossRef]

118. Zhan, M.; Xi, G. Urban territory spatial planning compilation for whole area and all elements control. Planners $2021,10,34$.

119. Lin, J.; Chen, X.; Xiao, W. Coordination Problems of Spatial Planning in China: International Lessons and Experiences. Mod. Urban Res. 2011, 12, 15-21. 
120. Shiyi, L.J.; WU YX, W.U.J.Y. Construction of the spatial planning system: With discussions on the relationship between spatial planning, territorial spatial regulation, and natural resources supervision. City Plan. Rev. 2018, 42, 9-17.

121. Lu, Y.; Zhao, M. On the Land-use Classification System in the Context of Territorial Spatial Planning: Classification Structure and Application Rationale. J. Urban Plan. 2021, 4, 51-57.

122. Zhao, M. On the construction logic and implementation agenda of the territorial development planning system of China. J. Urban Plan. 2019, 4, 8-15.

123. Cheng, Y.; Li, Y.; Zhao, M. Experience and lessons of EU marine spatial planning: The perspective of land and sea territorial integration. Urban Plan. Forum 2019, 5, 59-67.

124. Progress and Trend of Spatial Planning in Developed Countries in Last Decade Study on Sustainable Utilization of Land Resources and Construction of New Countryside in China. Available online: https: / /dysw.cnki.net $/ \mathrm{kcms} /$ detail $/$ detail.aspx?filename= TDYJ200807001119\&dbcode $=C P F D \& d b n a m e=C P F D 2014 \& v=($ accessed on 10 December 2021).

125. State of Arts on the Spatial Planning at Village Level. 2012. Available online: http://www.cqvip.com/qk/96793x/201201/40967 820.html (accessed on 10 December 2021).

126. Zhou, J.; Hu, T.; Zhu, Y. Construction of Dutch national spatial planning system and horizontal and vertical coordination mechanism. Planners 2017, 2, 35-41.

127. Liu, J. Policy Framework and Planning system of Territorial development in France: Characteristics and inspiration. City Plan. Rev. 2011, 35, 60-65.

128. Yu-mei, C.A.I.; Yan-li, G.A.O.; Jianping, Z.; Ting, H. Evolution And Illumination of American Spatial Planning System. Planners 2017, 2, 28-34.

129. Qian, H.; Luo, Z. Understanding the"Spatial Planning"Approach in Recent EU and the Implications for China. Urban Plan. Int. 2011, 26, 66-71.

130. Shi, W.; Wang, Y. European spatial planning implementation mechanism. Planners 2013, 29, 98-102.

131. Zhou, S.; Zhai, G.; Shi, Y. Spatial Planning Experience in England and Its Implications to China. Urban Plan. Int. 2017, 32, 82-89. [CrossRef]

132. Zhang, J.; Lin, H.; Chen, H. 40-Year Changes and Reforms of China's Spatial Planning System. Econ. Geogr. 2018, 38, 1-6.

133. Cai, Y.; Chen, M.; Chen, H. Overseas Spatial Planning Operation System Research Review. Planners $2014,30,83-87$.

134. Huang, S.; Liu, Y.; Wei, Z. Research Review on China's Territorial Spatial Planning: Knowledge Mapping Analysis Based on CiteSpace. South Archit. 2021, 3, 84-90.

135. Tian, Y.; Geng, H. Discussion on the Cohesion of Spatial Planning System of All Levels in the UK: The Case of Greater London Planning Practice. Urban Plan. Int. 2019, 34, 86-93. [CrossRef]

136. Yan, J.; Chen, H.; Xia, F. Cognition, Direction and Path of Future Spatial Planning based on the Background of Multiple Planning Integration. China Land Sci. 2017, 31, 21-27.

137. Turkelboom, F.; Leone, M.; Jacobs, S.; Kelemen, E.; García-Llorente, M.; Baró, F.; Termansen, M.; Barton, D.N.; Berry, P.; Stange, E.; et al. When we cannot have it all: Ecosystem services trade-offs in the context of spatial planning. Ecosyst. Serv. 2018, 29, 566-578. [CrossRef]

138. Xu, J.; Chi, S.; Hu, T.; Du, S.; Zhang, X. General Concept And Main Tasks Of Building Spatial Planning System in China. Planners 2017, 33, 5-11.

139. Zhang, X.; Wang, C.; Li, M. Demarcating ecological space and ecological protection red line under the framework of territory spatial planning. Geogr. Res. 2019, 38, 2431-2446.

140. Progress in Research of the Environmental Space Control System in China. 2016. Available online: http://www.neliwt.com/ article/doi/10.16803/j.cnki.issn.1004-6216.2016.03.001 (accessed on 10 December 2021).

141. Liu, Y.-P.; Han, Q.; Sun, Z.-Y.; Sun, C.-M.; Li, D. Establishment and application of one map of current situation of territorial spatial planning according to the foundations of natural resources: Taking Qingdao city as an example. J. Nat. Resour. 2019, 34, 2150-2162.

142. Sutrisno, D.; Darmawan, M.; Rahadiati, A.; Helmi, M.; Yusmur, A.; Hashim, M.; Shih, P.; Qin, R.; Zhang, L. Spatial-PlanningBased Ecosystem Adaptation (SPBEA): A Concept and Modeling of Prone Shoreline Retreat Areas. ISPRS Int. J. Geo-Inf. 2021, 10, 176. [CrossRef]

143. Gu, D.; Zhou, G. Low-Carbon-Oriented City Spatial Planning Strategy. Plan. Des. 2010, 11, 52-56.

144. Milovanović, A.; Rodić, D.M.; Maruna, M. Eighty-year review of the evolution of landscape ecology: From a spatial planning perspective. Landsc. Ecol. 2020, 35, 2141-2161. [CrossRef]

145. Research on Land-Ocean Planning Method in Territorial Space Planning. 2020. Available online: http://yuxiqbs.cqvip.com/ Qikan/Article/Detail?id=7102121051 (accessed on 10 December 2021).

146. Xu, Y.; Zhao, S.; Duan, J. Studies on the land use classification scheme for territory spatial planning. Geogr. Res. 2019, 38, 2388-2401.

147. Xu, J. The Flexibility, Scale And Mechanism Of Urban Development Boundary. Planners 2016, 32, 5-15.

148. Ouyang, W.; Wang, Y.; Lin, C.; He, M.; Hao, F.; Liu, H.; Zhu, W. Heavy metal loss from agricultural watershed to aquatic system: A scientometrics review. Sci. Total Environ. 2018, 637-638, 208-220. [CrossRef]

149. Ren, M.; Yu, X.; Mujumdar, A.S.; Yagoub, A.E.-G.A.; Chen, L.; Zhou, C. Visualizing the knowledge domain of pulsed light technology in the food field: A scientometrics review. Innov. Food Sci. Emerg. Technol. 2021, 74, 102823. [CrossRef] 
150. Sun, Y.; Wu, S.; Gong, G. Trends of research on polycyclic aromatic hydrocarbons in food: A 20 -year perspective from 1997 to 2017. Trends Food Sci. Technol. 2019, 83, 86-98. [CrossRef]

151. Zhong, B.; Wu, H.; Li, H.; Sepasgozar, S.; Luo, H.; He, L. A scientometric analysis and critical review of construction related ontology research. Autom. Constr. 2019, 101, 17-31. [CrossRef]

152. Zhang, J.; Jiang, L.; Liu, Z.; Li, Y.; Liu, K.; Fang, R.; Li, H.; Qu, Z.; Liu, C.; Li, F. A bibliometric and visual analysis of indoor occupation environmental health risks: Development, hotspots and trend directions. J. Clean. Prod. 2021, 300, 126824. [CrossRef]

153. Gandia, R.M.; Antonialli, F.; Cavazza, B.H.; Neto, A.M.; de Lima, D.A.; Sugano, J.Y.; Nicolai, I.; Zambalde, A.L. Autonomous vehicles: Scientometric and bibliometric review. Transp. Rev. 2018, 39, 9-28. [CrossRef]

154. Li, Q.; Long, R.; Chen, H.; Chen, F.; Wang, J. Visualized analysis of global green buildings: Development, barriers and future directions. J. Clean. Prod. 2020, 245, 118775. [CrossRef]

155. Liu, X.; Zhao, S.; Tan, L.; Tan, Y.; Wang, Y.; Ye, Z.; Hou, C.; Xu, Y.; Liu, S.; Wang, G. Frontier and hot topics in electrochemiluminescence sensing technology based on CiteSpace bibliometric analysis. Biosens. Bioelectron. 2022, 201, 113932. [CrossRef]

156. Sheikhnejad, Y.; Yigitcanlar, T. Scientific Landscape of Sustainable Urban and Rural Areas Research: A Systematic Scientometric Analysis. Sustainability 2020, 12, 1293. [CrossRef]

157. Zheng, C.; Yuan, J.; Zhu, L.; Zhang, Y.; Shao, Q. From digital to sustainable: A scientometric review of smart city literature between 1990 and 2019. J. Clean. Prod. 2020, 258, 120689. [CrossRef]

158. Wang, X.; Zhang, Y.; Zhang, J.; Fu, C.; Zhang, X. Progress in urban metabolism research and hotspot analysis based on CiteSpace analysis. J. Clean. Prod. 2021, 281, 125224. [CrossRef]

159. Zhang, D.; Xu, J.; Zhang, Y.; Wang, J.; He, S.; Zhou, X. Study on sustainable urbanization literature based on Web of Science, scopus, and China national knowledge infrastructure: A scientometric analysis in CiteSpace. J. Clean. Prod. 2020, 264, 121537. [CrossRef]

160. Li, J.; Weng, G.; Pan, Y.; Li, C.; Wang, N. A scientometric review of tourism carrying capacity research: Cooperation, hotspots, and prospect. J. Clean. Prod. 2021, 325, 129278. [CrossRef]

161. Vardiambasis, I.O.; Kapetanakis, T.N.; Nikolopoulos, C.D.; Trang, T.K.; Tsubota, T.; Keyikoglu, R.; Khataee, A.; Kalderis, D. Hydrochars as Emerging Biofuels: Recent Advances and Application of Artificial Neural Networks for the Prediction of Heating Values. Energies 2020, 13, 4572. [CrossRef]

162. Li, B.; Xu, D.; Feng, L.; Liu, Y.; Zhang, L. Advances and prospects on the aquatic plant coupled with sediment microbial fuel cell system. Environ. Pollut. 2022, 297, 118771. [CrossRef] [PubMed]

163. Alvarez-Peregrina, C.; Martinez-Perez, C.; Villa-Collar, C.; Sánchez-Tena, M. A Bibliometric and Citation Network Analysis of Myopia Genetics. Genes 2021, 12, 447. [CrossRef]

164. Sanchez-Tena, M.A.; Martinez-Perez, C.; Villa-Collar, C.; Alvarez-Peregrina, C. Impact of COVID-19 at the Ocular Level: A Citation Network Study. J. Clin. Med. 2021, 10, 1340. [CrossRef]

165. Nascimento, H.; Martinez-Perez, C.; Alvarez-Peregrina, C.; Sánchez-Tena, M.Á. Citations Network Analysis of Vision and Sport. Int. J. Environ. Res. Public Health 2020, 17, 7574. [CrossRef]

166. Xu, X.; Mishra, G.D.; Jones, M. Mapping the global research landscape and knowledge gaps on multimorbidity: A bibliometric study. J. Glob. Health 2017, 7, 010414. [CrossRef]

167. Bilias, F.; Nikoli, T.; Kalderis, D.; Gasparatos, D. Towards a Soil Remediation Strategy Using Biochar: Effects on Soil Chemical Properties and Bioavailability of Potentially Toxic Elements. Toxics 2021, 9, 184. [CrossRef]

168. Hernández, C.; Echeverría, C.; Nelson, C. Evolution and emerging research trends in the ecological impacts of landscape change: Perspectives from a Chilean biodiversity hotspot. Landsc. Ecol. 2021, 36, 1587-1603. [CrossRef]

169. Huang, L.; Kelly, S.; Lv, K.; Giurco, D. A systematic review of empirical methods for modelling sectoral carbon emissions in China. J. Clean. Prod. 2019, 215, 1382-1401. [CrossRef]

170. Huang, L.; Zhou, M.; Lv, J.; Chen, K. Trends in global research in forest carbon sequestration: A bibliometric analysis. J. Clean. Prod. 2020, 252, 119908. [CrossRef]

171. Yu, D.; Xu, C. Mapping research on carbon emissions trading: A co-citation analysis. Renew. Sustain. Energy Rev. 2017, 74, 1314-1322. [CrossRef]

172. Ji, Z.; Pei, Y. Bibliographic and visualized analysis of geopolymer research and its application in heavy metal immobilization: A review. J. Environ. Manag. 2019, 231, 256-267. [CrossRef]

173. Zhang, X.; Gao, Y.; Yan, X.; de Pablos, P.O.; Sun, Y.; Cao, X. From e-learning to social-learning: Mapping development of studies on social media-supported knowledge management. Comput. Hum. Behav. 2015, 51, 803-811. [CrossRef]

174. Li, X.; Ma, E.; Qu, H. Knowledge mapping of hospitality research-A visual analysis using CiteSpace. Int. J. Hosp. Manag. 2017, 60, 77-93. [CrossRef]

175. Liu, Y.; Zhou, Y. Territory spatial planning and national governance system in China. Land Use Policy 2021, 102, 105288. [CrossRef]

176. Song, R.; Hu, Y.; Li, M. Chinese Pattern of Urban Development Quality Assessment: A Perspective Based on National Territory Spatial Planning Initiatives. Land 2021, 10, 773. [CrossRef]

177. Dong, Z. Natural Resource Asset Management and Land and Spatial Planning. Landsc. Archit. Front. 2019, 7, 88-93. [CrossRef] 